\title{
Play distribution and the hydrocarbon potential of the Mannar Basin, Sri Lanka
}

\author{
E. K. C. W. Kularathna ${ }^{1,2} \cdot$ H. M. T. G. A. Pitawala ${ }^{2,3} \cdot$ A. Senaratne ${ }^{3} \cdot$ A. S. Ratnayake ${ }^{4}$
}

Received: 19 December 2019 / Accepted: 2 May 2020 / Published online: 12 May 2020

(c) The Author(s) 2020

\begin{abstract}
The Mannar Basin is a frontier failed rift basin between India and Sri Lanka. The Sri Lankan part has an area exceeding $42,000 \mathrm{~km}^{2}$. Although the recent two gas discoveries have confirmed the existence of an active petroleum system in the Mannar Basin, a major portion of the basin is still poorly explored. This article summarized the progress of current exploration activities and the hydrocarbon potential of the Mannar Basin. This basin began to evolve since the Upper Jurassic and experienced two rifting events; an early Late Jurassic syn-rift phase associated with East-West Gondwana break up; and a later, earliest Cretaceous syn-rift phase associated with Antarctica separation from greater India around $142 \mathrm{Ma}$. Rifting was followed by a post-rift phase comprising a thermal sag period and an inversion period. Three potential source rocks intervals have been interpreted at Maastrichtian-Campanian, Albian-Aptian, and Late Jurassic stratigraphic levels. The basin modelling work has confirmed that (1) mature potential source rocks (mainly Type II) exist below the Maastrichtian-Campanian strata and (2) the best potential source rocks (mainly Type II) exist at Albian-Aptian stratigraphic levels. The Late Jurassic source rocks have more potential for gas, while other sources have potential for both oil and gas. According to basin modelling results, Maastrichtian-Campanian and Albian-Aptian source rocks reach the oil window in the present-day depocentre around $45 \mathrm{Ma}$ and $80 \mathrm{Ma}$, respectively. The Late Jurassic source rocks (mainly Type III) reach the gas window around $112 \mathrm{Ma}$ in the present-day depocentre. Five play levels were defined for the whole stratigraphic section of the Mannar Basin. Tertiary play level is dominated by submarine fans, mounds and rollover anticline like structures. The Upper Cretaceous play is dominated by forced-fold structures, intra-basalt turbidite sands, and sub-volcanic sand-rich systems. The Lower Cretaceous play is dominated by reefs and abrupt margin pinch outs. The Upper Jurassic play is dominated by abrupt margin pinch outs. The Basement play consists of weathered basement rocks. The main challenge of the Mannar Basin is imaging below the flood volcanic layer, which inhibits the penetration of seismic energy and results in low-quality seismic data. Therefore, hydrocarbon potential assessments have become a major challenge below the Upper Cretaceous. The interpretation shows that the basin has a low risk for the source and reservoir, and high risk for seal and traps. New exploration activity would unlock more potential areas for hydrocarbon accumulations. Finally, the findings of this study can help for better understanding of hydrocarbon potential areas and current progress of exploration activities in the Mannar Basin, Sri Lanka.
\end{abstract}

Keywords Sri Lanka $\cdot$ Mannar basin $\cdot$ Petroleum system $\cdot$ Hydrocarbon play

E. K. C. W. Kularathna

kularathna.c@gmail.com

1 Petroleum Resources Development Secretariat, Level 06, Ceylinco House 69, Janadhipathi Mawatha, Colombo 01, Sri Lanka

2 Postgraduate Institute of Science, University of Peradeniya, P.O. Box 25, Peradeniya, Sri Lanka

3 Department of Geology, Faculty of Science, University of Peradeniya, Peradeniya, Sri Lanka

4 Faculty of Applied Sciences, Uva Wellassa University, Passara Road, Badulla 90000, Sri Lanka

\section{Introduction}

Approximately, 90\% of the Sri Lankan landmass is composed of high-grade metamorphic rocks of granulite to amphibolite facies (Cooray 1984). The rest of the landmass, consisting of a narrow belt almost parallel to the western and northern coastal margin, and the offshore portion consists of sedimentary rocks. Three offshore sedimentary basins, namely Cauvery, Mannar, and Lanka, have been demarcated in Sri Lanka (Fig. 1). The Mannar Basin is the largest and most prolific hydrocarbon province in Sri Lanka. 


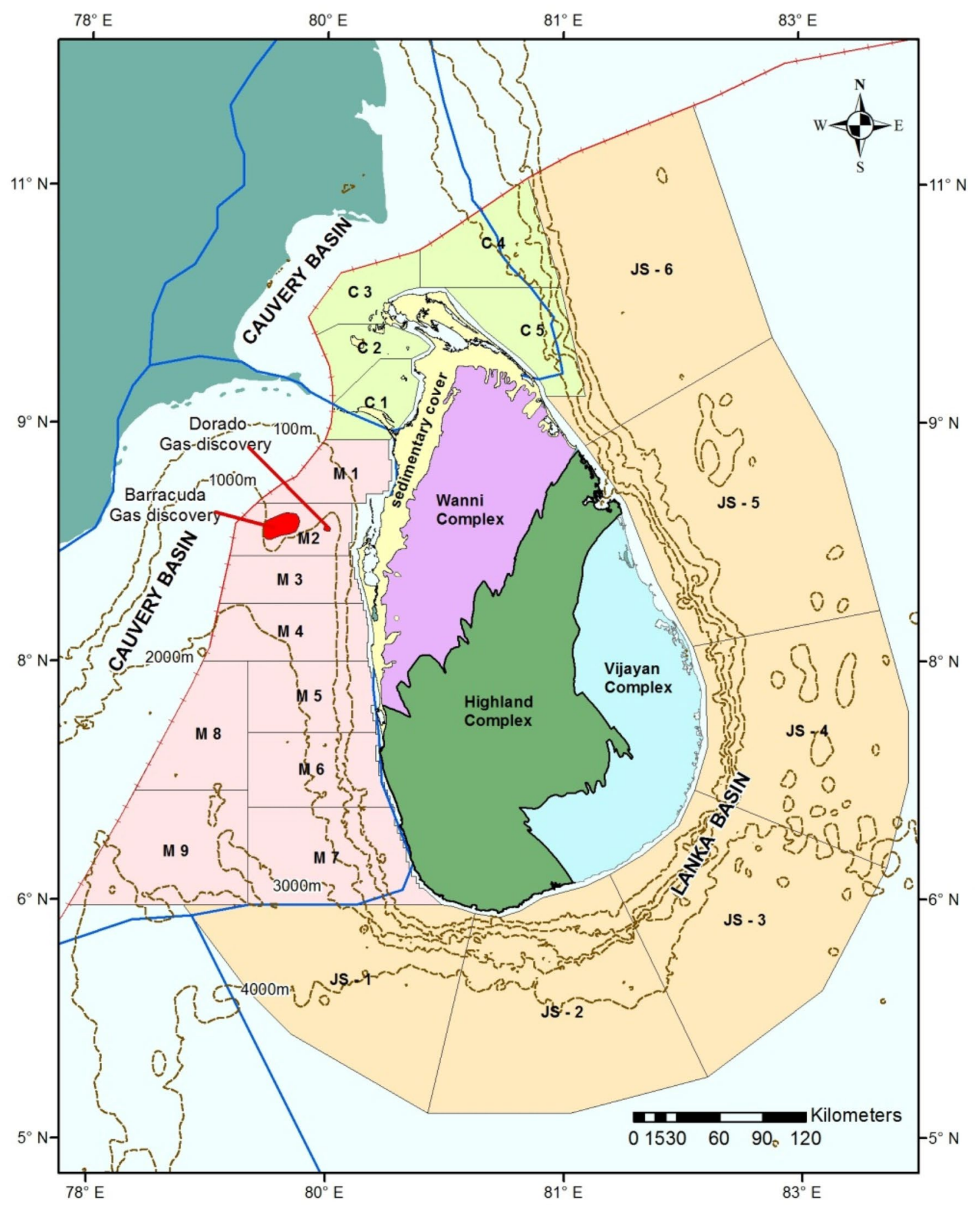

Fig. 1 Location of the three sedimentary basins (Cauvery, Mannar, and Lanka) in Sri Lanka, exploration blocks in the Mannar Basin (M1-M9), the Cauvery Basin (C1-C5) and Joint study blocks in the Lanka Basin (JS1-JS6)

The Mannar Basin is located to the southwest and northwest of Sri Lanka, southeast of India and south of the Cauvery Basin (Fig. 1). It forms an intra-cratonic failed rift between India and Sri Lanka, and the Sri Lankan side of the Mannar Basin has an area exceeding 42,000 $\mathrm{km}^{2}$. The water depth of the basin varies from $200 \mathrm{~m}$ to over $3000 \mathrm{~m}$, and the majority of the basin is at water depths greater than $1000 \mathrm{~m}$ making it a deepwater sedimentary basin. The Petroleum Resources Development Secretariat (PRDS) has divided the Mannar Basin into nine exploration blocks for prospecting hydrocarbons. Although exploration in the basin is limited (described below), two gas/condensate discoveries 
were made in 2011 (Fig. 1). These discoveries are located in the north part of the basin, and they prove the existence of a petroleum system. However, most of the basin remains very poorly explored, and the basin is thus considered as a frontier.

In this study, available data at the PRDS were used to identify hydrocarbon plays and leads. In addition, petroleum system modelling was performed to understand the hydrocarbon potential of the Mannar Basin. Consequently, this article reviews the current progress of the hydrocarbon exploration of the Mannar Basin, Sri Lanka.

\section{Hydrocarbon exploration statuses and data availability}

Petroleum exploration in Sri Lanka began in the late 1950s. There were two main episodes: the old era and the new era. The old era is the period from 1957 to 1984 , during which exploration was mainly confined to the shallow water portion of the Cauvery and Mannar Basins (Ratnayake et al. 2017). In this period, a total of approximately $9030 \mathrm{~km}$ of
2D seismic data were acquired, and seven wells were drilled (Fig. 2). Out of the seven wells drilled, two wells of Pesalai 1 and 2 have shown gas in Early Cretaceous sandstones. There was no exploration activity from 1984 to 2001 .

The new era is the period from 2001 to Present. In 2001, Ceylon Petroleum Corporation and Tomlinson Geophysical Services (TGS)/Norwegian Petroleum Exploration Consultants (NOPEC) signed an agreement to acquire 1216.9-line $\mathrm{km}$ of 2D seismic data (labelled as SL 01 data) in the Mannar Basin. The data were interpreted by Newsouth Global Pty Ltd in 2002. The unpublished report suggests significant potential for hydrocarbons in the deepwater Mannar Basin. Therefore, TGSNOPEC decided to acquire an additional 4479-line km of 2D seismic data in 2005 (labelled as SL 05 data). These two TGSNOPEC surveys provided high-quality 2D seismic data in the Mannar Basin (Fig. 3). In 2007, the government of Sri Lanka bought the Mannar Basin 2D data from TGSNOPEC. Therefore, the agreement between the Government of Sri Lanka and TGSNOPEC was cancelled.

The Mannar Basin was divided into nine exploration blocks size ranging from 3340 to $8127 \mathrm{~km}^{2}$ (Fig. 1). Three blocks of M2, M3, and M4 were opened in a licensing round

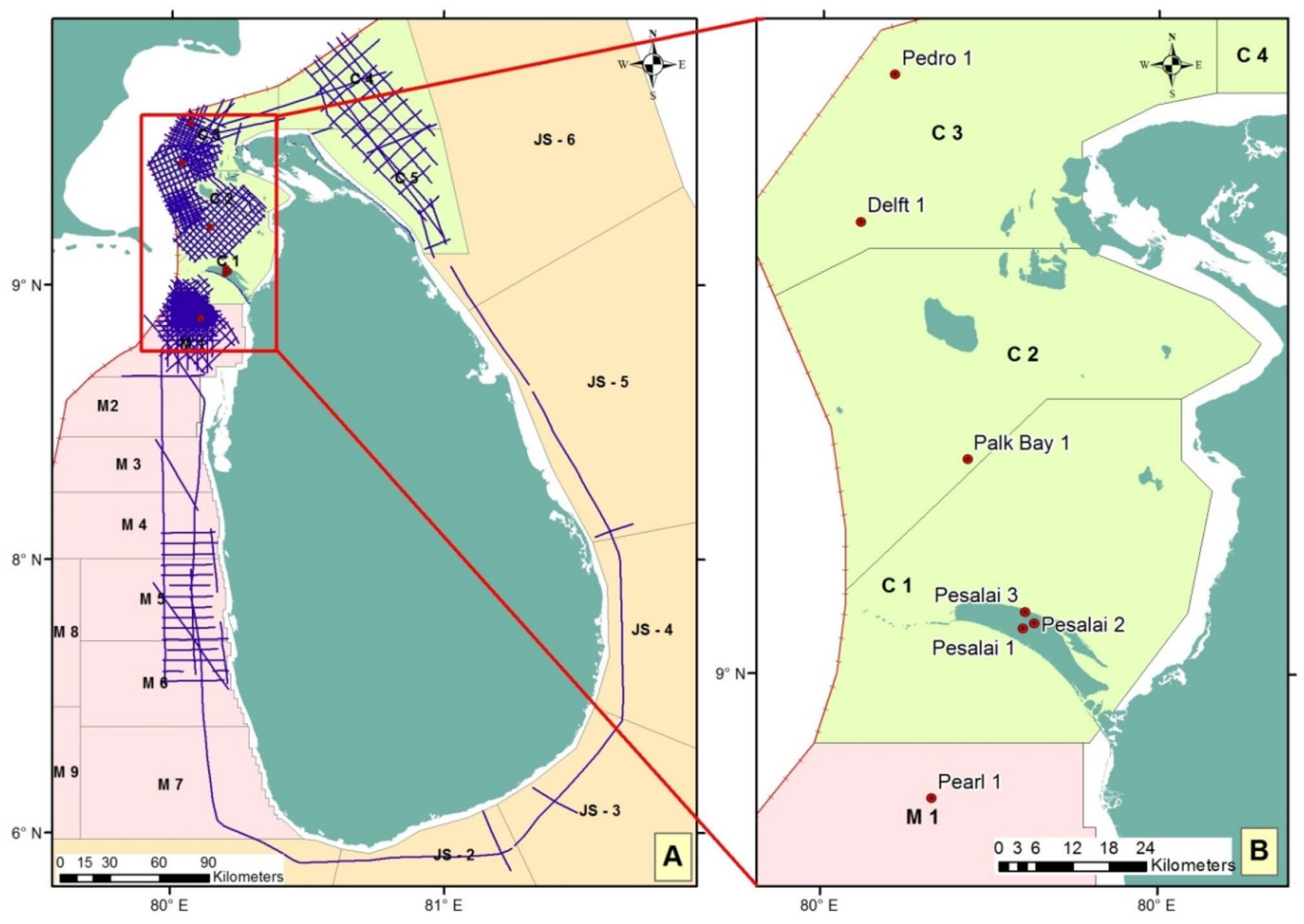

Fig. 2 Seismic data (blue lines) acquired 1957-1984 (old era). Insert map shows wells drilled in the old era 


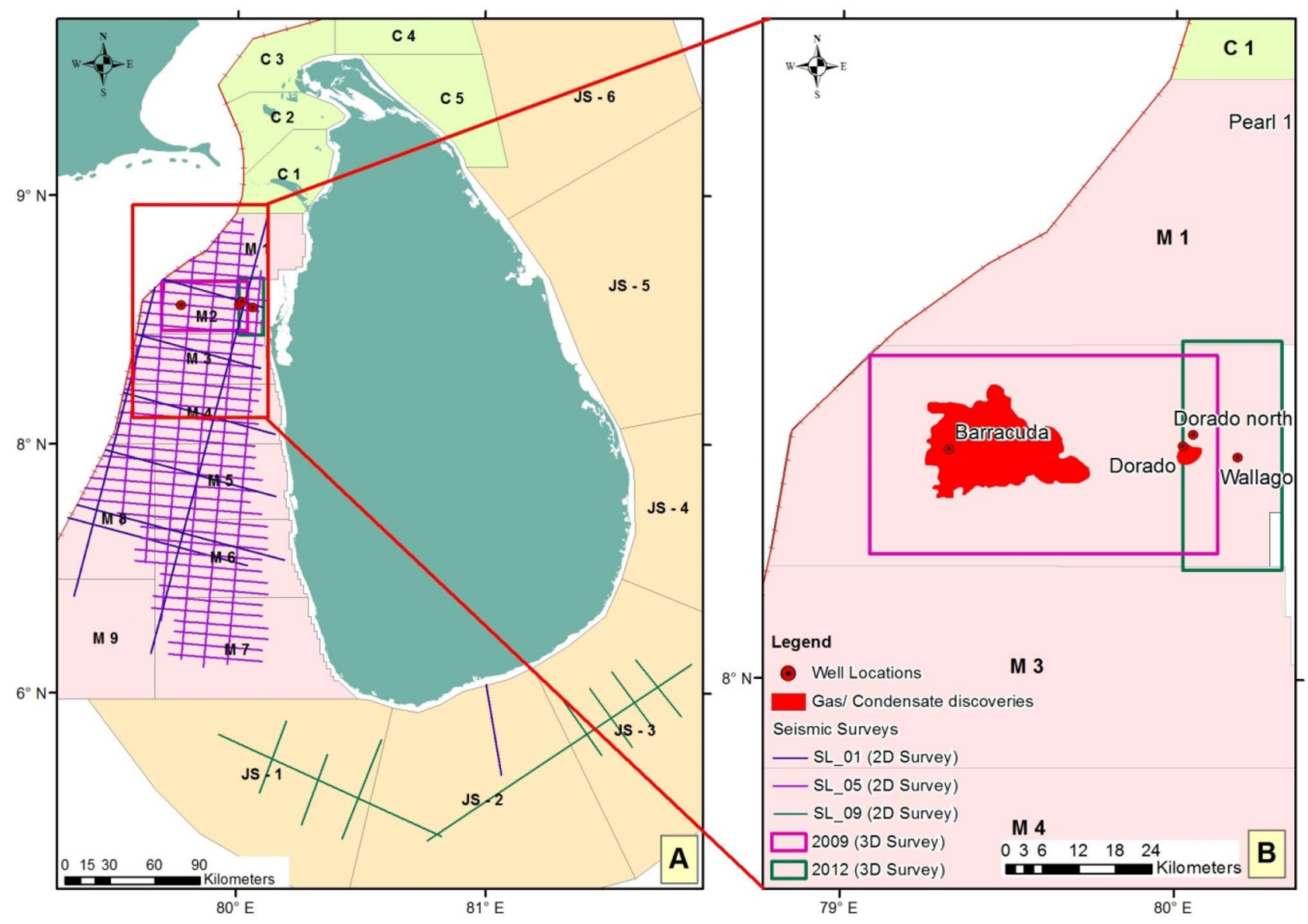

Fig. 3 Acquired seismic data in the new era (post 2001). Inserted map shows the well locations and 3D seismic survey areas in the new era

in 2007. Three bids were received for block M2, two bids for block M3 and one bid for block M4. The government of Sri Lanka awarded the block M2 to Cairn Lanka (Private) Limited in 2008. Cairn conducted the first 3D seismic survey in block M2 in 2009. In the same year, the government of Sri Lanka conducted a 2D seismic survey in the southern part of the Lanka Basin. After processing and interpretation of the 3D seismic data, three exploratory wells were drilled in 2011 namely Dorado, Barracuda and Dorado North (Fig. 3). Natural gas/condensates were discovered in the Dorado and Barracuda wells. Cairn conducted another $3 \mathrm{D}$ seismic survey in 2012, and Wallago exploration well was drilled in 2013 (Fig. 3). Cairn relinquished block M2 in 2016. In the same year, the government of Sri Lanka entered into an agreement with Total to conduct a joint study program for the blocks JS-5 and JS-6. In 2016, SL-05 seismic data were reprocessed and depth migrated (Fig. 3).

The petroleum data acquired since early exploration days are available at the PRDS, and the Mannar Basin data were utilized for this study. Seismic and potential field data, well data and several interpretation reports are available at the PRDS data room, and relevant published data and reports were incorporated together with new simulations for this study. Interpretations from the report of Shaw (2002) were also incorporated for the definition of potential hydrocarbon plays and leads in the Mannar Basin. In this paper, play distribution and the hydrocarbon potential were assessed using the Petroleum System Quick Look (PSQL) plugging, built-in Petrel software.

\section{Tectonostratigraphy}

The tectonostratigraphic evolution of the Mannar Basin (Fig. 4) can be distinguished broadly as pre-rift, rift and post-rift (Allen and Allen 2005). The pre-rift sedimentary section of the Mannar Basin has been interpreted from 200 to $165 \mathrm{Ma}$. However, no direct evidence was recorded in well data or rock exposures to demonstrate the presence of this sequence in the Mannar Basin. It has been interpreted that prominent bright amplitude packages present just above the basement horizon signify the pre-rift sedimentary section. The depositional environment can be interpreted as continental (Fig. 5). Shaw (2002) mentioned that Karroo-type 


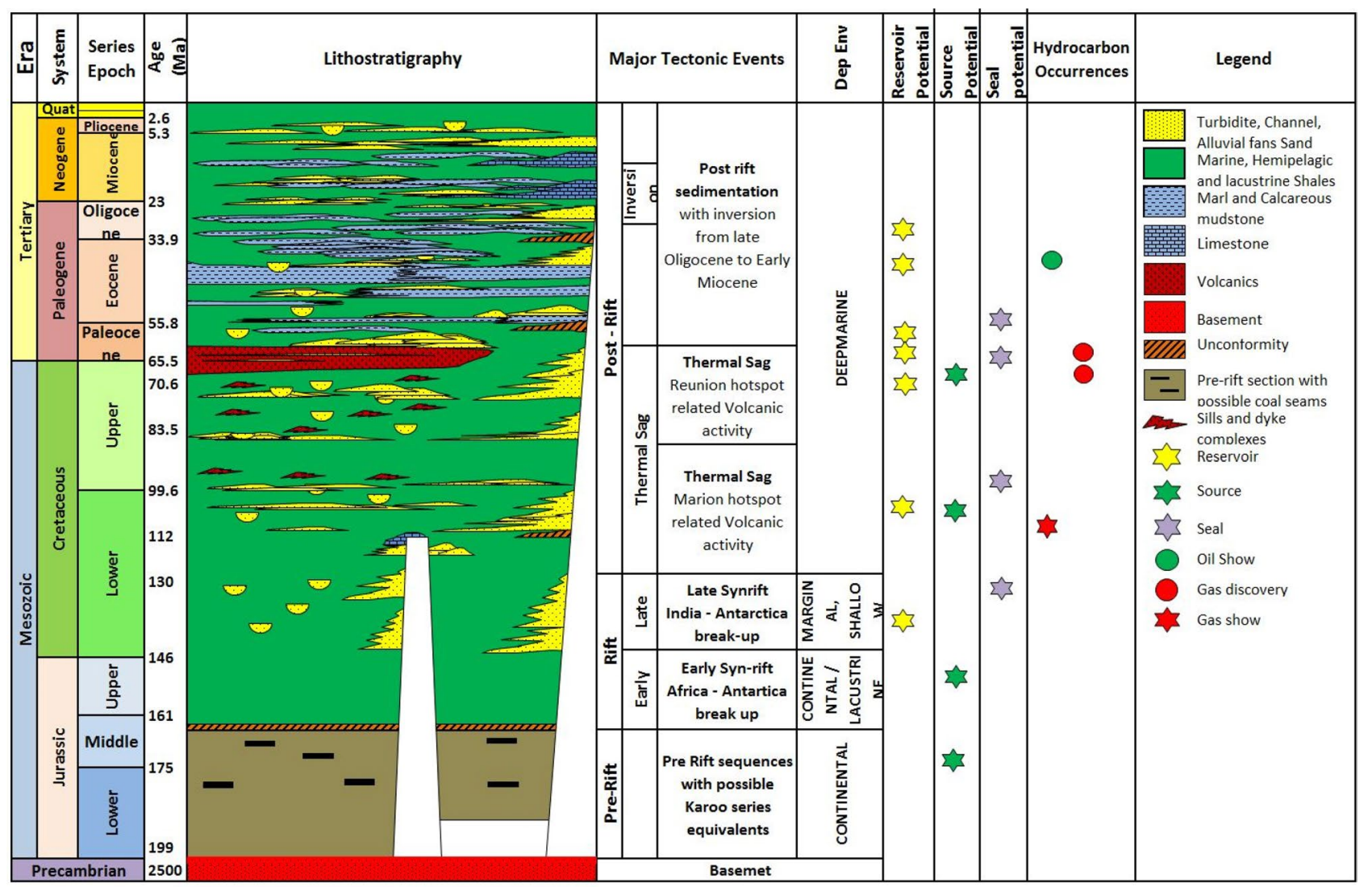

Fig. 4 Generalized stratigraphic column of the Mannar Basin based on the seismic data (SL01, SL05), well data (Pearl 1, Dorado, Dorado North, and Barracuda) and relevant publications (e.g. Ichron 2012a, b, c)

coals could be present in this section. Similar occurrences are present in the proto-Somali Basin, Godavari-Krishna Basin and Madagascar (Stanca et al. 2016). At this age, Sri Lanka was a part of East Gondwana (Fig. 5), although the initial configuration of Sri Lanka within East Gondwana is still uncertain (Royer et al. 1992; Ramana et al. 2001; Desa et al. 2006; Bandara et al. 2020).

The rifting episode in the Mannar Basin has been divided into two periods: early syn-rift and late syn-rift (Shaw 2002; Ratnayake et al. 2014; Kularathna et al. 2015). The early rifting stage of the Mannar Basin was initiated with the East-West Gondwana breakup during the Late Jurassic period (ca. $165 \mathrm{Ma}$ ) (Royer and Coffin 1992). In this phase, the Mannar Basin opened by possible counter-clockwise rotation of Sri Lankan landmass away from greater India (Shaw 2002; Kularathna et al. 2015). The sedimentary section developed in this phase is named as the early syn-rift (Fig. 6). The sediment depositional environment can be interpreted as lacustrine to transitional and probably extends to the shallow marine conditions (Kularathna et al. 2015).

The late syn-rift phase of the Mannar Basin was initiated in Early Cretaceous times (Fig. 7) after the splitting of East and West Gondwana, Madagascar, Seychelles, and
Greater India were separated from Australia and Antarctica (Schlich 1982; Mizukoshi et al. 1986). Magnetic anomaly M11 (134 Ma) recorded by Desa et al. (2006) suggests that the late syn-rift phase began before this isochron, probably ca. 142 Ma. The southern and eastern margins of Sri Lanka were directly attached to Antarctica, so the oldest magnetic M11 isochron between 110 and $140 \mathrm{~km}$ south of Sri Lanka confirms this late syn-rift phase seafloor spreading. This suggests more effective extensional forces in the late synrift phase (Royer and Coffin 1992). The large extent of rifting together with strike-slip movement and more counterclockwise rotation caused a significant widening and rapid subsidence of the basin. It suggests that the formation of the Cauvery and Lanka Basins were initiated during this phase (Kularathna et al. 2015; Bandara et al. 2020). The oldest magnetic anomaly M11 shows that the late syn-rift phase was complete around $134 \mathrm{Ma}$ ago (Fig. 8) and was replaced by the development of oceanic crust around Sri Lanka.

The post-rift stage of the Mannar Basin dates from Early Cretaceous times (134 Ma), during which the basin underwent thermal sagging similar to a passive margin (Fig. 8). This was interrupted by igneous activity such as flood basalts which seem to have a connection with Deccan flood basalt in 


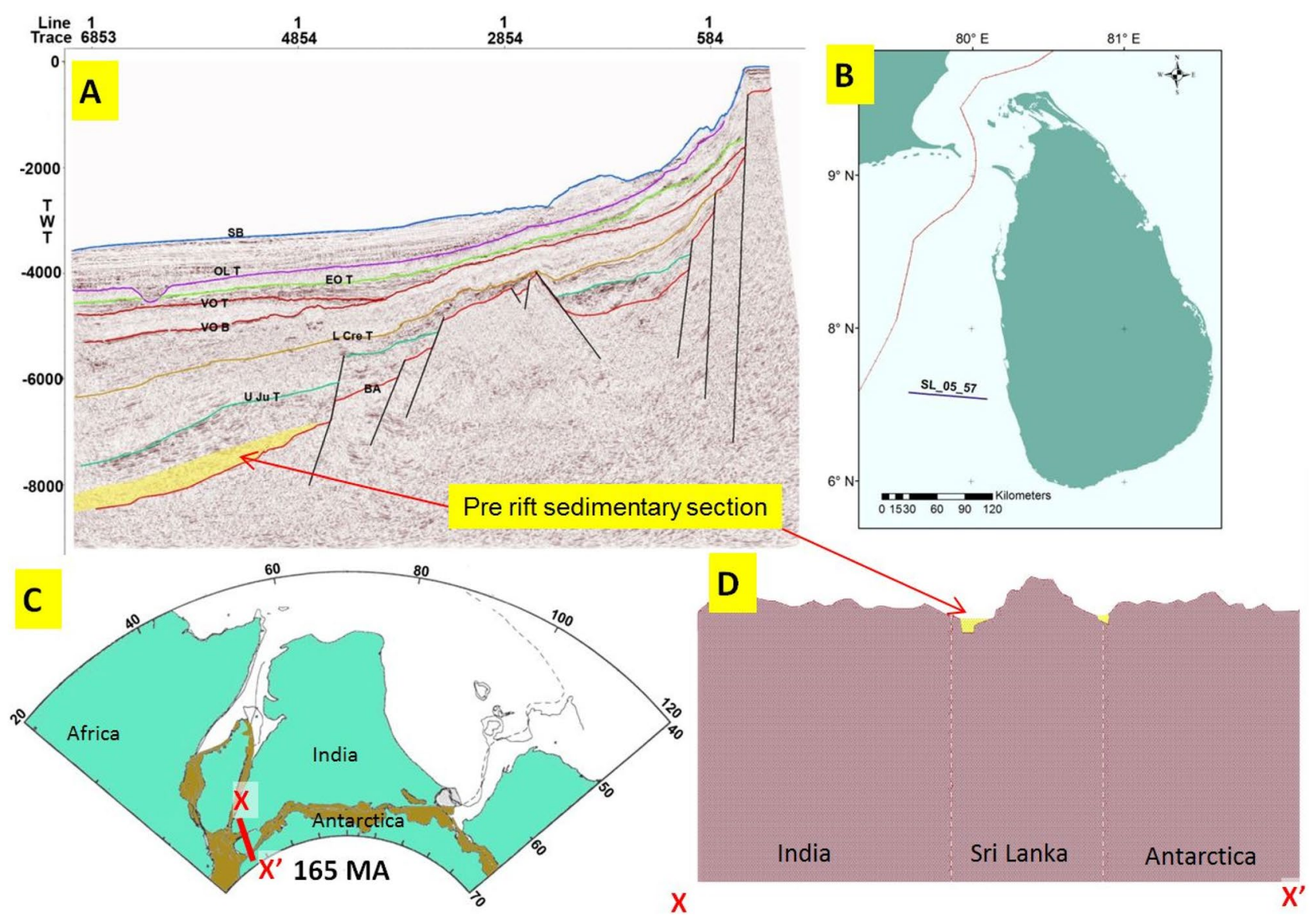

Fig. 5 a Seismic line SL-05-57 depicting the pre-rift sediments above the horizon BA (Basement Top). b Base map showing the location of the line SL-05-57. c Plate tectonic reconstruction at $165 \mathrm{Ma}$. Seafloor spreading has begun between East and West Gondwana and off north-

India that originates from the Reunion hotspot (Kularathna et al. 2015; Ratnayake and Sampei 2015b). The seismic data in the basin show an Eocene inversion that is associated with the Himalayan orogeny (Fig. 8).

\section{Source rock potential}

Previous studies have discussed the source rock potential in the Mannar Basin using geochemical results of drill-cuttings from Dorado, Dorado North, Wallago and Barracuda exploration wells and 1D basin modelling interpretations (e.g. Ratnayake et al. 2018; Ratnayake and Sampei 2019). According to the literature, the Campanian-Maastrichtian, Albian and Late Jurassic source rocks can be considered as the best potential source rocks of the Mannar Basin. In this paper, 3D basin modelling was performed for the selected regional seismic horizons in the Mannar Basin. The horizons were selected to represent the potential source rocks levels in the Mannar Basin. It was assumed that a $100 \mathrm{~m}$ west Australia. d Schematic cross section through India-Sri LankaAntarctica around $165 \mathrm{Ma}$, depicting the arrangement of India, Sri Lanka and Antarctica in west Gondwanaland and the possible pre-rift section anticipated for the Mannar Basin

thick and evenly distributed source rock existed below each surface. The modelling results infer source rocks behaviours, if source rocks exist with the same chemical and physical character at the level being modelled. In this study, 3D basin modelling was performed using the Petroleum System Quick Look (PSQL) plugin. The plugin is capable of providing an initial rapid screening of the hydrocarbon source and reservoir with a simulation of maturation, migration, and accumulation.

The quickly simulated results can be compared with geological scenarios through maps of source rock maturation, hydrocarbon generation, location of accumulations, and hydrocarbon migration pathways (Mukherjee and Mahapatra 2013). The 2-component kinetic model defined by Pepper and Corvi (1995) has been built in the PSQL plugin for Type I, Type II and Type III kerogen. The PSQL plug-in is capable of providing adequate and acceptable results considering the geological, geochemical, geophysi$\mathrm{cal}$, and tectonostratigraphic evolution uncertainties. The possible kerogen types were forecast by considering the 


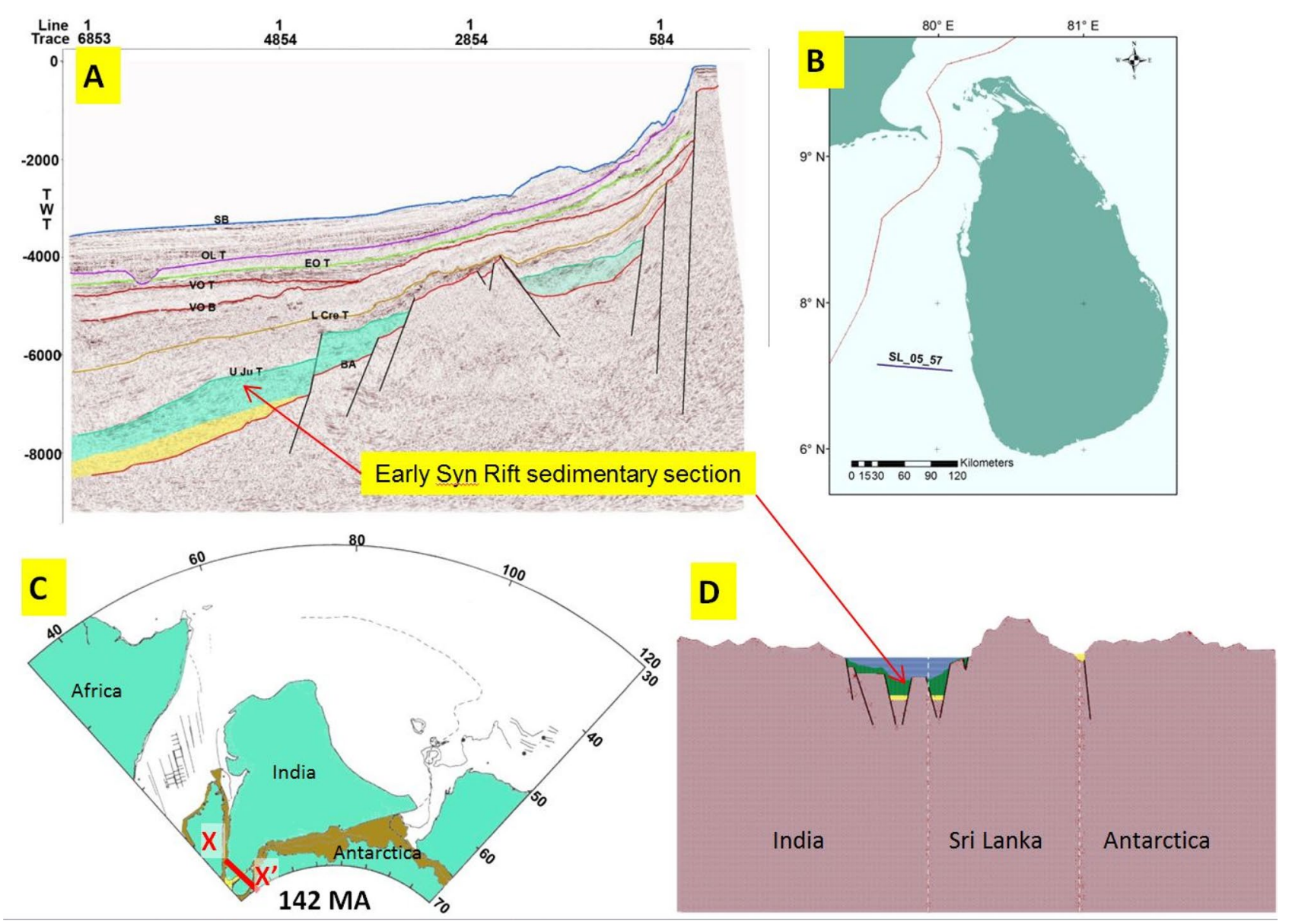

Fig. 6 a Seismic line SL-05-57 depicting the early syn-rift sediments below the top Upper Jurassic (U Ju T) horizon. b A base map showing the location of line SL-05-57. c Plate tectonic reconstruction at $142 \mathrm{Ma}$ representing the end of the early syn-rift phase and the configuration of the east Gondwanaland and opening of the Mannar
Basin. Seafloor spreading has just begun between Madagascar-Seychelles-India-Sri Lanka and Australia-Antarctica. d Schematic cross section through India-Sri Lanka-India around $142 \mathrm{Ma}$, depicting the arrangement of India, Sri Lanka and Antarctica in the west Gondwanaland and the early syn-rift section in the Mannar Basin paleo-depositional environments supported by indirect and direct evidence (Fig. 4). For example, continental to lacustrine environments were interpreted during Late Jurassic times or in the early syn-rift phase. Consequently, Type III source rock is inferred below the surface of the Upper Jurassic (e.g. Ratnayake and Sampei 2015a). The basin is interpreted to have been in a deep marine depositional environment during the Albian-Aptian and Campanian to Maastrichtian, and Type II source rock can thus be expected (Ratnayake et al. 2018). Total organic carbon (TOC) values were also considered for the source rocks horizons. Besides, generalized HI values were considered for the source rocks (i.e. high hydrogen index (HI) values for Type II and low HI values for Type III) kerogen (Pepper and Corvi 1995). Average seabed temperatures and average thermal gradients were obtained for modelling based on the data from Ichron limited reports (Ichron limited 2012a, b, c, 2013).

\section{Upper Jurassic source rock potential}

Late Jurassic source rocks belong to the early syn-rift phase. None of the wells drilled in the Mannar Basin have penetrated Late Jurassic sedimentary rocks. Therefore, direct evidence regarding the presence of these rocks in the basin is not available. However, coals and lacustrine shale sources of kerogen Type I and Type III are possible in this phase (Shaw 2002). Jurassic rocks are found locally in Tabbowa and Andigama areas in fault bound mini basins (Cooray 1984; Ratnayake and Sampei 2015a). The Tabbowa Beds comprise of arkosic sandstones, but no detailed investigation has been carried out to identify the exact extension of Tabbowa Basin or its stratigraphy. The Andigama Beds, comprise arkosic sandstones and carbonaceous shales with thin coal beds, found in very restricted areas. These carbonaceous shales have high TOC content of 3.05-5.10\% (Ratnayake and Sampei $2015 \mathrm{a}$ ). These Jurassic mini basins were also formed 


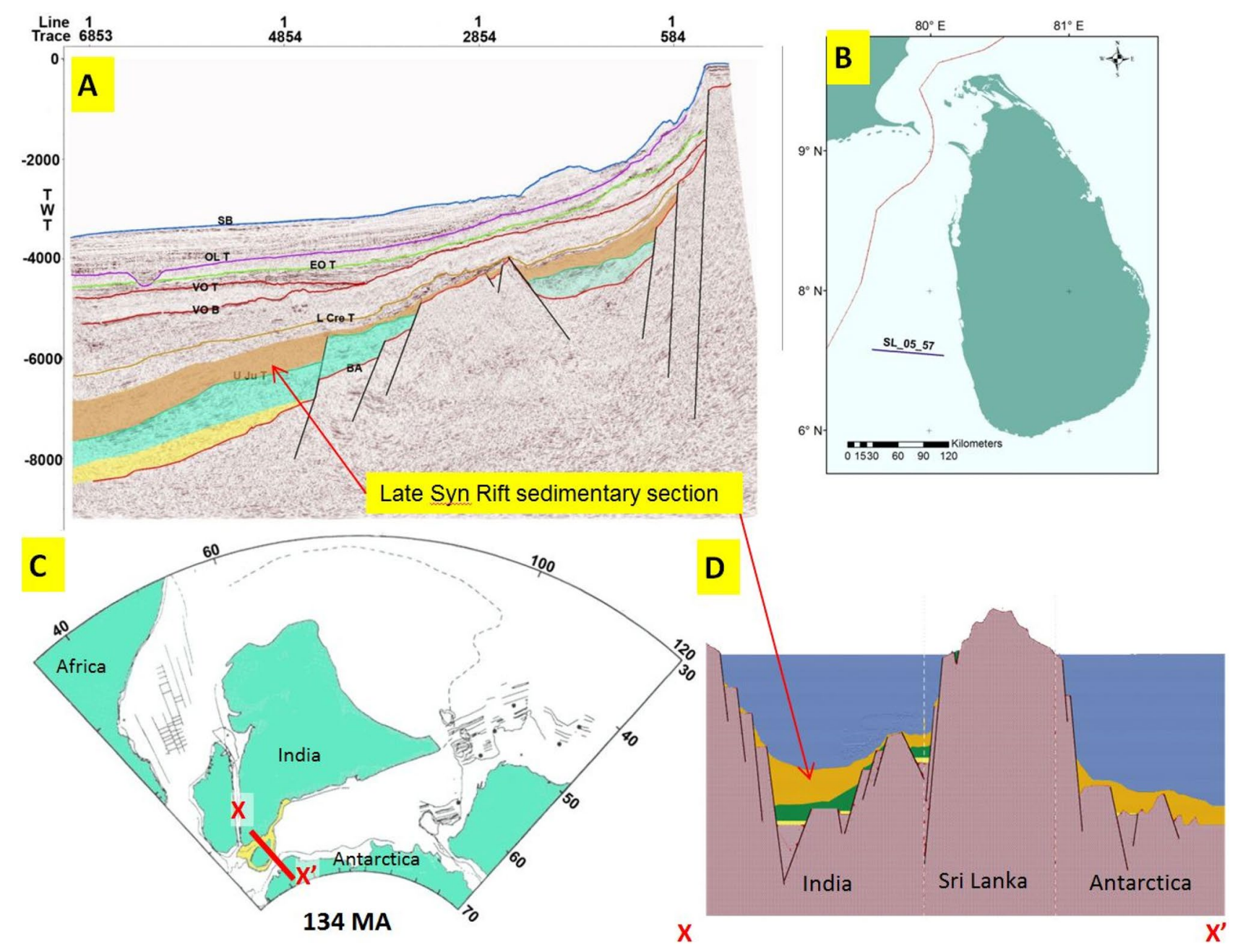

Fig. 7 a Seismic line SL-05-57 depicting the late syn-rift sediments above top Upper Jurassic ( $\mathrm{U} \mathrm{Ju} \mathrm{T}$ ) horizon. b A base map showing the location of line SL-05-57. c Plate tectonic reconstruction at 134 Ma representing the end of the late syn-rift phase and the configuration of east Gondwanaland (i.e. further widening of the Mannar Basin, opening the Cauvery Basin and opening the Lanka Basin).

with the East-West Gondwana separation corresponding to early syn-rift phase in the Mannar Basin. Consequently, rocks similar to Tabbowa and Andigama could occur in the deeper parts of the Mannar Basin. In addition, Late Jurassic formations such as Shivganga Beds and Therani Formation on the Indian side of the Cauvery Basin show source rock potential (Directorate General of Hydrocarbons (DGH) website) and in the Krishna-Godavari Basin, the Late JurassicEarly Cretaceous syn-rift mega-sequence comprises largely non-marine units possibly providing Type III and Type I source rock potential (Shaw 2002; Galushkin 2016).

The basin modelling results show that close to the present day depocentre related Late Jurassic sources (Type III and Type I) are over mature (yellow colour) and close to the basin margin source rocks are either immature or in an
Oceanic crust develops between Madagascar-Seychelles-India-Sri Lanka and Australia-Antarctica. d Schematic cross section through India-Sri Lanka-Antarctica around $134 \mathrm{Ma}$, depicting the arrangement of India, Sri Lanka and Antarctica in the west Gondwanaland and the late syn-rift section in the Mannar Basin

early oil window (light to dark green colour and blue colour) (Section (A) in Fig. 9a). At the present day depocentre, these source rocks have entered the main oil window at $130 \mathrm{Ma}$ (Section (A) in Fig. 9b) and entered the gas window around $112 \mathrm{Ma}$ (Section (A) in Fig. 9c).

\section{Albian-Aptian source rock potential}

Albian-Aptian source rocks belong to the post-rift phase, and evidence regarding the potential source rocks is available from well data and publicly available information from adjacent basins. The Pesalai 1 well was drilled close to the Mannar Basin margin. This well penetrated an approximately $300 \mathrm{~m}$ thick source rock bed with $6 \%$ TOC and $\mathrm{HI}$ value of $350 \mathrm{mg} \mathrm{HC/g}$ TOC in the Albian 


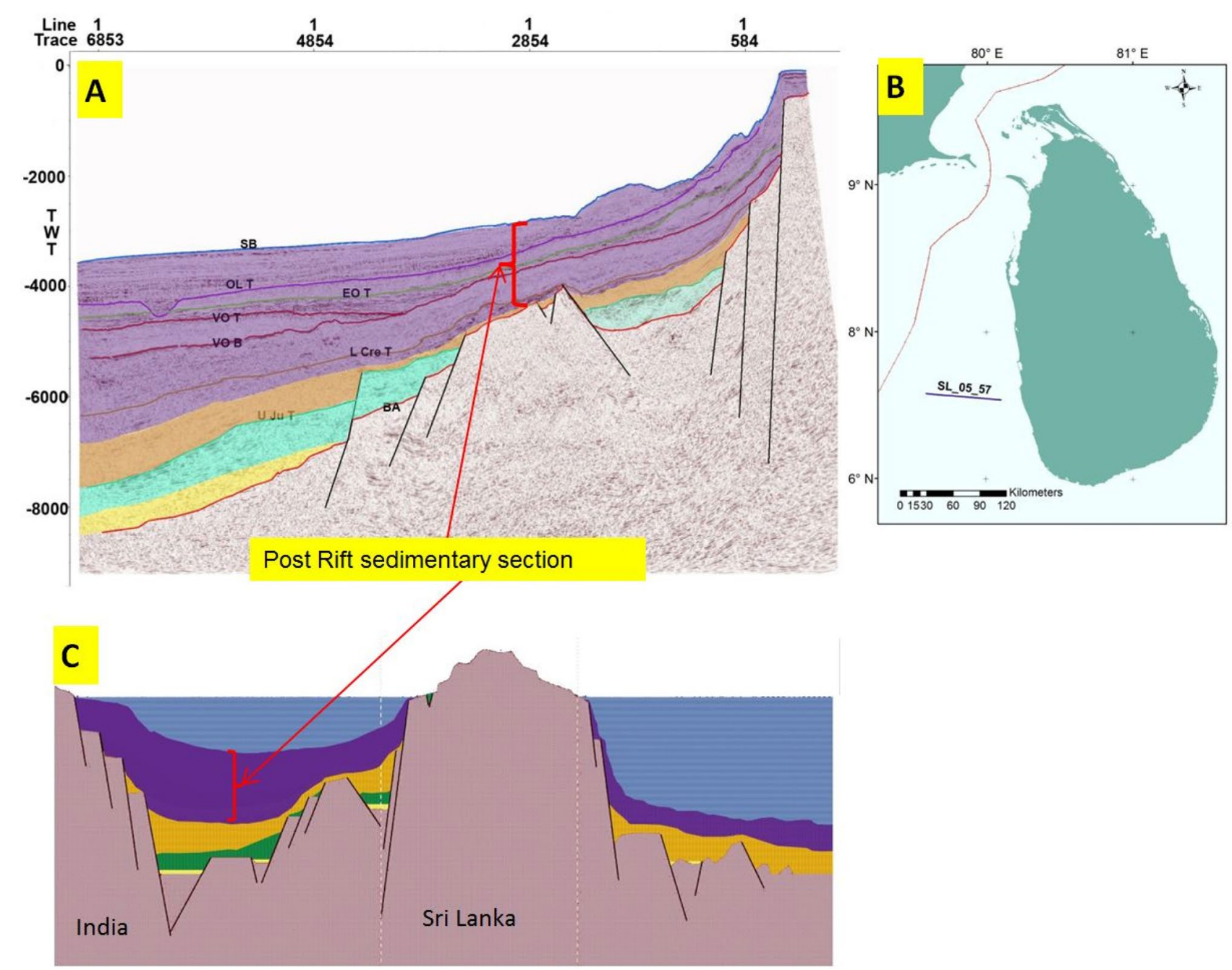

Fig. 8 a Seismic line SL-05-57 depicting the post-rift sedimentary section. b A base map showing the location of line SL-05-7. c Present cross section through the Mannar and Lanka Basins, and the post-rift sedimentary section in the Mannar Basin

interval. These strata have been interpreted as marine shales of kerogen Type II (Cernock 1976). The Director General of Hydrocarbon (DGH) India reveals that Albian age Sattapadi and Andimadan Formations in the Cauvery Basin have demonstrated good quality source potential. In addition, major oceanic anoxic events (OAEs) were associated with the massive pre-Albian to Cenomanian marine transgression (e.g. Schlanger and Jenkyns 1976; Arthur and Schlanger 1979; Rullkötter and Mukhopadhyaya 1984) and further extended up to Coniacian times after the Turonian regression (Tissot and Welte 1984). The widespread marine anoxia during the OAEs was associated with a significant burial of organic carbon on the ocean floor under oxygen-deficient bottom water conditions (Turgeon and Creaser 2008). Consequently, the best source-rocks may be formed in the deeper parts of the oceanic basins during the transgressive phase of sedimentation in the Cretaceous. Nagendra and Reddy (2017) identified the signatures of globally significant oceanic anoxic events of OAE-1b, OAE-1d, OAE-2, and OAE-3 in the Cauvery Basin though not OAE-1c. OAE $1 b$ and OAE- $1 c$ are of Albian age. This event can be inferred to form better source rocks in the deepwater Mannar Basin than in the shallow water Cauvery Basin. Anoxic event OAE-1c may form source rocks in the deepwater Mannar Basin.

The basin modelling results show that close to the present day depocentre, Albian-Aptian sources (Type II) are in the dry gas window (brownish-orange colour) and close to the basin margin source rocks are either immature (blue colour) or in an early oil window (light to dark green colour) (Section (C) in Fig. 9a). At the present day depocentre, these source rocks entered the main oil window around $80 \mathrm{Ma}$ and at later times towards the basin margin (Section (C) in Fig. 9b). In addition, some areas close to the basin margin have not reached to the oil window yet (Section (C) in Fig. 9b). At the depocentre, the rocks entered the gas 
Fig. 9 a Maturity maps of potential source rocks. Where, yellow colour (\%Ro 5.0-4.5) indicates the over mature window, brownish orange colour (\%Ro 4.5-2.0) indicates the dry gas window, red colour (\% Ro 1.0-1.3) indicates the wet gas window, light to dark green colour (\%Ro 1.3-0.5) indicates the oil window and blue colour (\%Ro 0.5-0) indicates the immature window, b geological time at which each potential source rock levels enters the main oil window and $\mathbf{c}$ geological time at which each potential source rock levels enters the gas window. Where, (A) Late Jurassic Type I source rocks, (B) Late Jurassic Type III source rocks, (C) Albian Type II source rocks (D) Campanian-Maastrichtian Type II source rocks $\mathbf{a}$

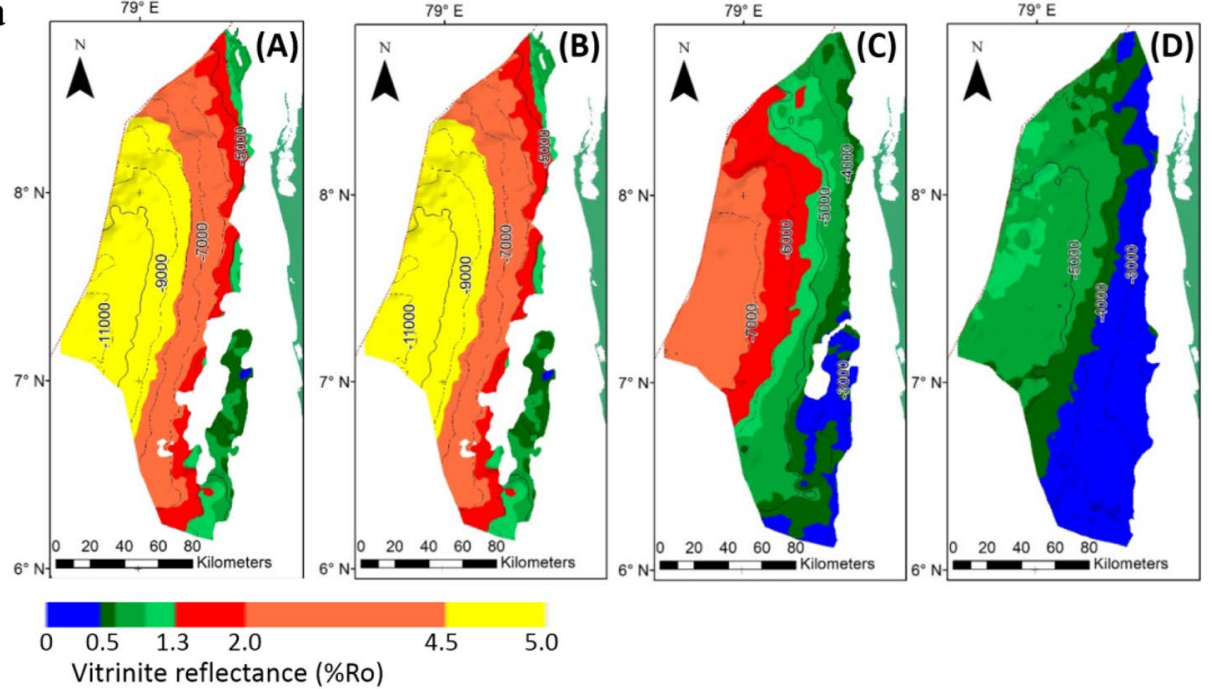

b

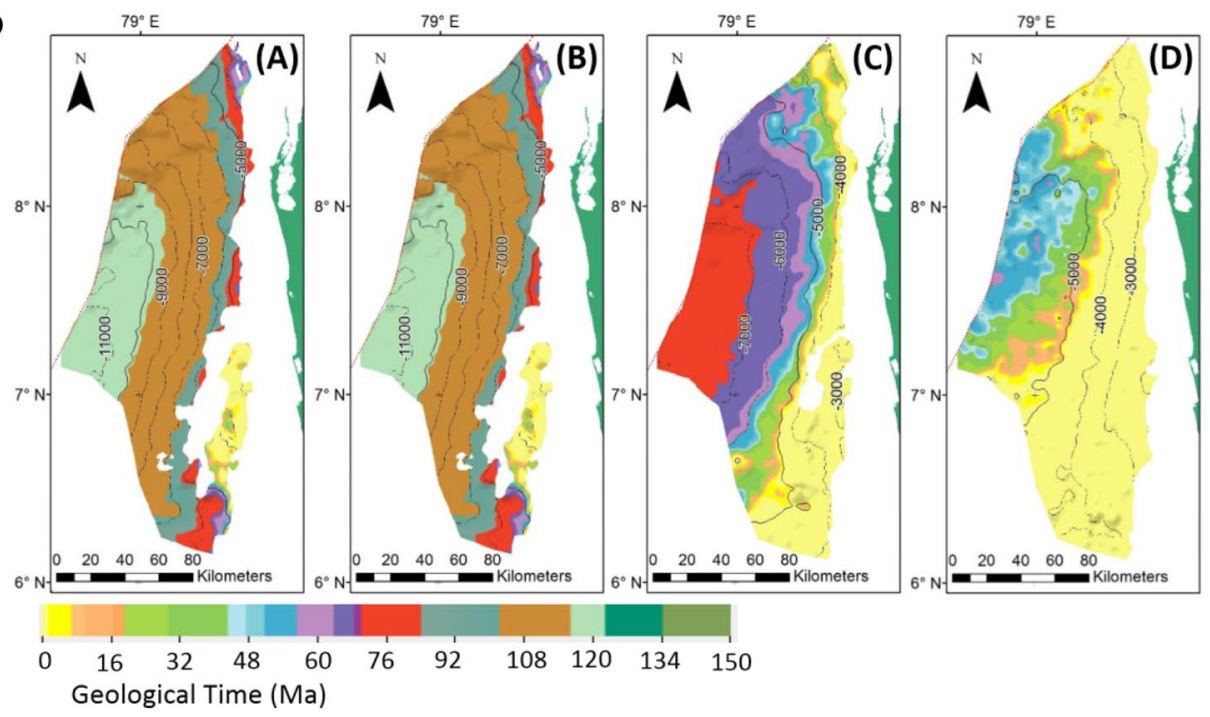

c

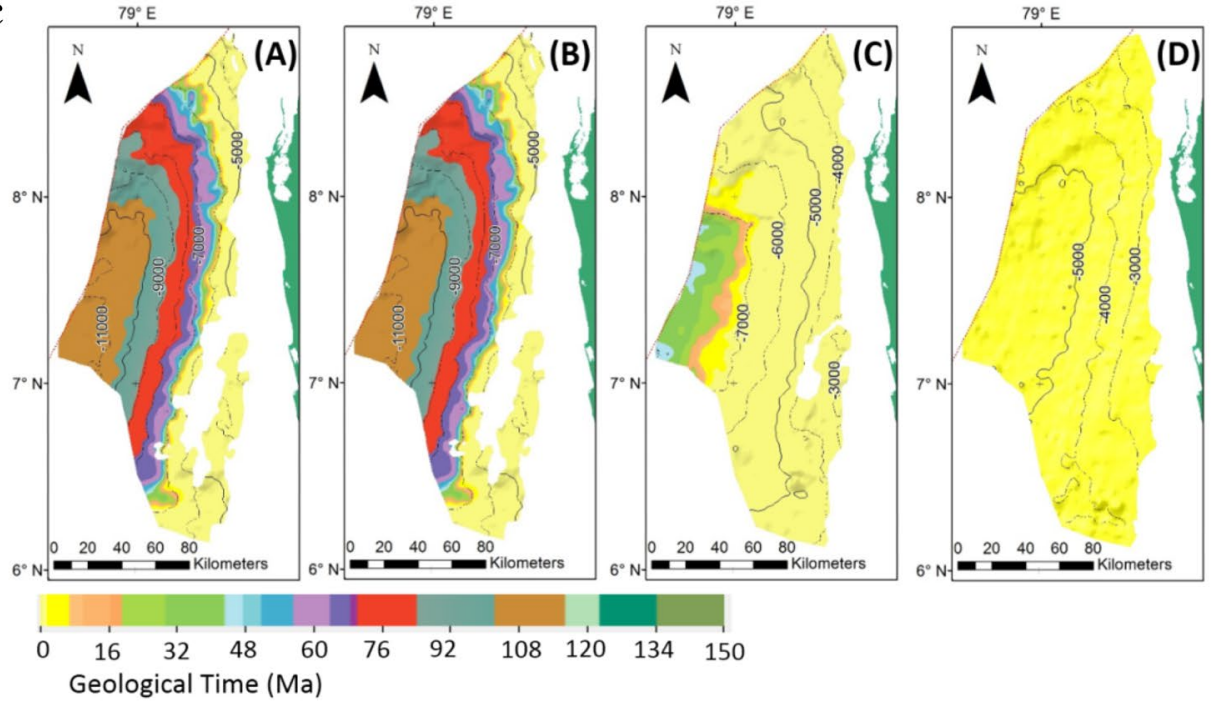


window around $50 \mathrm{Ma}$ and with decreasing age towards the basin margin (Section (C) in Fig. 9c).

\section{Maastrichtian-Campanian source rock potential}

Maastrichtian-Campanian source rocks also belong to the post-rift stage and evidence regarding the potential source rocks is available from well data and publicly available information of the adjacent basins. The Dorado, Barracuda and Dorado North exploration wells in the Mannar Basin have penetrated the Maastrichtian-Campanian age rocks. The potential source rocks with Type II and Type III kerogen have been identified (Ichron limited 2012a, b, c). The Campanian-Maastrichtian Kudavasal shale (Type II and Type III) is interpreted as the main source on the Indian side of the Cauvery Basin (DGH website).

The basin modelling results show that Maastrichtian-Campanian sources (Type II) are at an oil window (light to dark green colour) close to the present-day depocentre, and towards the basin margin maturity decreases to the immature stage (blue colour) (Section (D) in Fig. 9a). These sources rocks entered the main oil window around $45 \mathrm{Ma}$ in the depocentre and later towards the basin margin (Section (D) in Fig. 9b). In addition, the major areas close to the basin margin have not yet reached the oil window (Section (D) in Fig. 9b). Furthermore, even at the present day depocentre they have not entered the gas window yet (Section (D) in Fig. 9c).

\section{Play and lead identification}

A hydrocarbon play is a group of accumulations and prospects that resemble each other geologically, by source rock potential, reservoir, seal and trap conditions (Doust 2010; Olayiwola and Dejam 2019). A play can be identified as either proven or unproven. Play analysis can be used to find undiscovered petroleum potential of an area being assessed (Magoon and Dow 1994; Dakhelpour-Ghoveifel et al. 2019). A lead in hydrocarbon exploration is a subsurface structural or stratigraphic feature located on available geophysical data such as seismic which has the potential to entrap oil or natural gas. Play and lead identification were conducted on the seismic data acquired in 2001 and 2005. In this study, five play levels were defined based on the major geological time boundaries as discussed below.

\section{Tertiary play level}

Sedimentary strata between the top Pliocene and top Cretaceous are named the Tertiary play level (Fig. 10a). The sediments at this level developed under an open marine, deepwater slope to basin-floor environment. Several inversion structures can be observed on the seismic data, and these inversion structures were developed by the tectonic forces applied by the collision of the Indo-Australian plate and Eurasian plate in Oligocene-Miocene times. Well data demonstrate that the Eocene to Miocene period is dominated by carbonates, predominantly marl with sandstone and shale sequences (Ichron limited 2012a, b, c; Ratnayake 2016). The Palaeocene strata of the Tertiary play level are dominated by sandstones and shales. The major plays and leads interpreted on seismic data are basin floor fans, mounds and roll over anticlinal structures (Fig. 10b).

Massive basin floor fan complexes can be identified with high and variable seismic amplitudes at this play level. Most of the fans were deposited during the Paleocene. Major fan complexes are located to the west and northwest of the basin margin (Fig. 10). These fans have a channelized-lobe architecture. Therefore, the Paleocene can be considered a sand-rich system (Richards and Bowman 1998), and good quality reservoir rock characteristics (i.e. high permeability and porosity) can be anticipated at this play level. Vertical and lateral hydrocarbon migration can occur from deep sources into these fan complexes. A flood volcanic layer underlies the Tertiary play. This volcanic layer possibly behaves as a barrier for the vertical migration of hydrocarbon from the pre-Tertiary layers. However, where the flood volcanic layer is discontinuous, it may permit vertical migration of hydrocarbons to the Tertiary play. Mud rocks dominate the Eocene and Oligocene sedimentary sequences providing a top-seal for this play (Ichron limited 2012a, b, c). Assessment of the lateral extents and up-dip sealing is challenging with the available seismic data coverage.

At the Tertiary play level, roll over anticlines can be interpreted on the seismic data and these structures are mainly located in the south of the Mannar Basin (Fig. 10). Such structures contain hydrocarbon accumulations in the offshore Niger Delta (Nyantakyi et al. 2013). In the Mannar Basin, the formation of these structures may be associated with the Himalayan orogeny. Carbonate mound like structures can be observed on the seismic data in the northern part of the basin (Fig. 10). Formation of such deep water mounds has been documented in the Rockall Basin (Wilson 1979) Bahama Basin (Mullins et al. 1981) and Norwegian shelf (Mortensen et al. 1995). Carbonate mounds act as four-way dip closures for hydrocarbon accumulation in the Mannar Basin. The Tertiary plays have been ready for hydrocarbon accumulation since the end of the Palaeocene (ca. $55 \mathrm{Ma}$ ), and these plays could have been charged by all of the interpreted source rock intervals as soon as they became mature. 


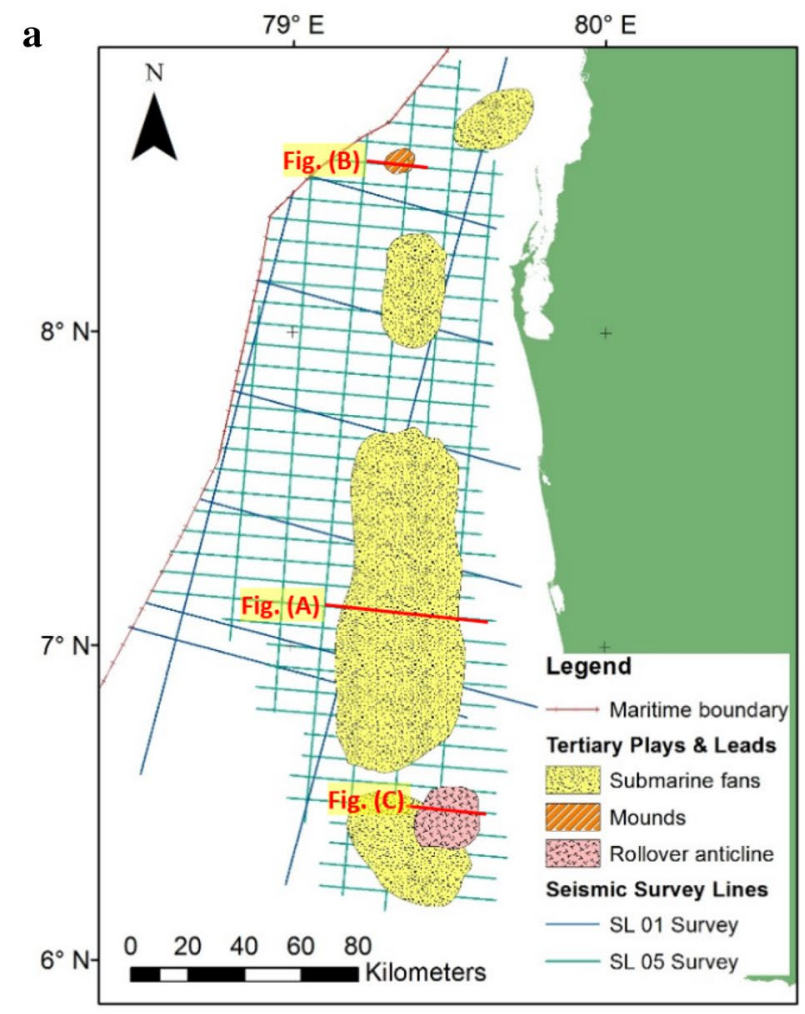

b
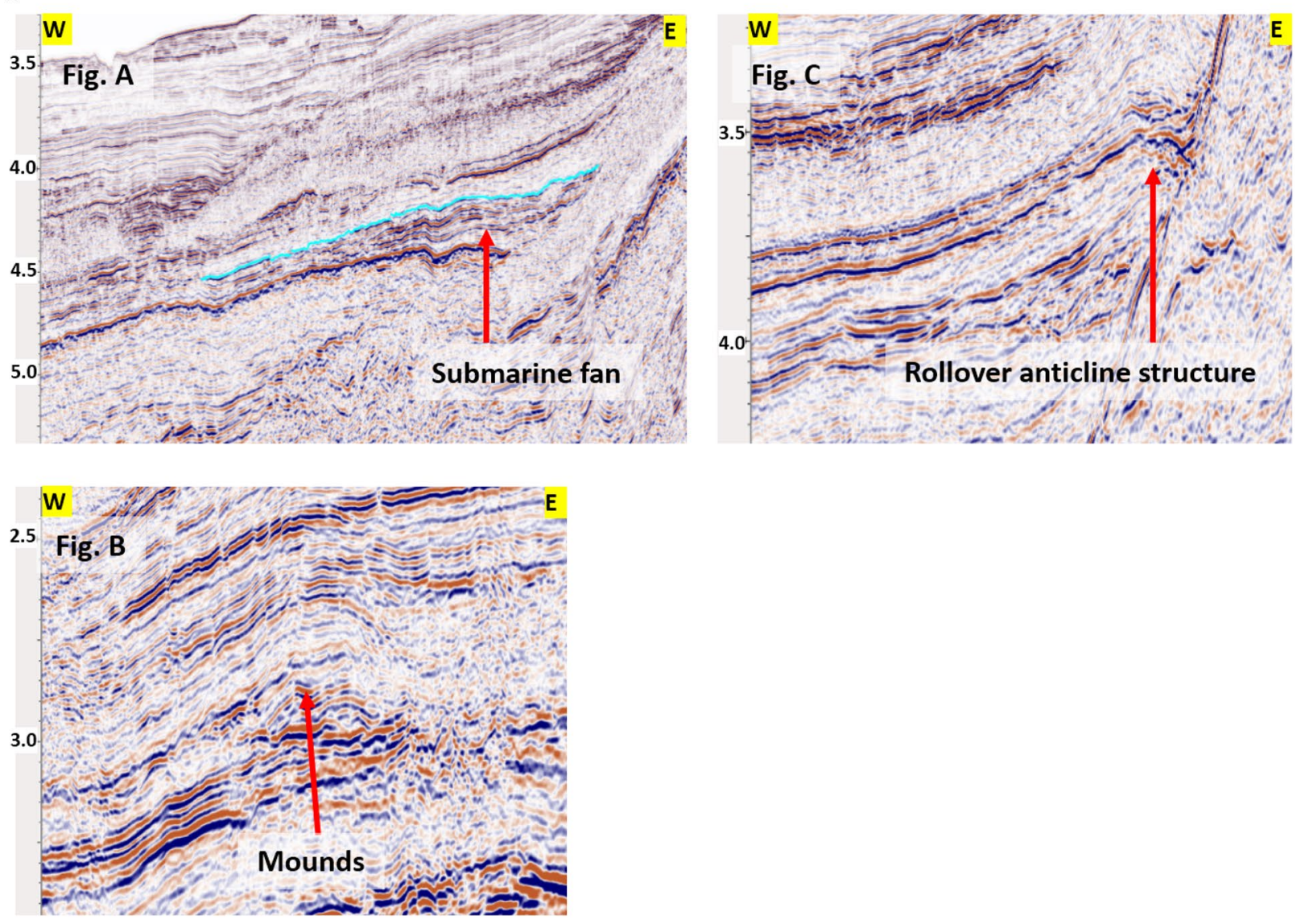
4Fig. 10 a Map showing the distribution of the Tertiary plays in the Mannar Basin. b Seismic profiles showing potential Tertiary plays, (A) submarine fan, (B) mounds like structure, and (C) Rollover anticline like structure

\section{Upper Cretaceous play level}

The Late Cretaceous sedimentary strata are named the Upper Cretaceous play level. The major plays and leads are forcedfold structures, intra-basalt turbidite sands and sub-volcanic sand-rich systems (Fig. 11).

Forced-folds are also known as jacked-up structures that are associated with igneous intrusions (Du Toit 1920; Hotz 1952). The growth of forced-fold structures can be directly linked to the mechanical emplacement of the intrusive body and can serve as traps for hydrocarbon accumulation (Hansen and Cartwright 2006). Forced-fold structures in the Mannar Basin occur as both isolated and cluster types. The clusters of forced-fold structures have generated relatively larger scale folding at the top Cretaceous horizon. These structures are dominant towards the present day depocentre, and isolated structures are commonly located close to the margin of the basin (Fig. 11). The Dorado gas/condensate discovery in the Mannar Basin was encountered in a forcedfold structure.

The intra-volcanic turbidite sand play is also a proven play encountered within the flood volcanic layer of the Mannar Basin. The Barracuda gas/condensate was encountered in intra-volcanic turbidite sand layers (Fig. 11). These sand layers were deposited in Campanian-Maastrichtian times between lava flows. High and variable seismic amplitudes are observed immediately below the flood volcanic bottom horizon (Fig. 11). These sand-rich systems are interpreted as turbidites, fans or channels. The mapping and prediction of the continuity and areal extent of these sands is very challenging due to seismic imaging complications below the flood volcanic layer. Consequently, understanding of the reservoir properties has also become problematic. The flood volcanic layer may act as the seal for the sand layers. High density and low permeability of the flood volcanic layer may prevent the vertical migration of hydrocarbons. Therefore, charging of hydrocarbons into intra-volcanic sands is a risk. However, high fractured areas in the flood volcanic layer provide paths for vertical migration of hydrocarbon.

Sediments draping over basement highs could also act as a play. The formation of this play begins with sediment deposition over the basement high followed by differential compaction (Fig. 11). Sand-rich turbidites or fans are the anticipated reservoir, and mudrocks are assumed to be the potential seal. Vertical and lateral migration of hydrocarbons from deep-seated sources is possible and charging risk and trap risks are low. In summary, Late Cretaceous plays and leads have ready for hydrocarbon accumulation since the end of Maastrichtian (ca. $65 \mathrm{Ma}$ ) and these plays could be charged by all the interpreted source rock intervals.

\section{Lower Cretaceous play level}

The Early Cretaceous sedimentary strata are named the Lower Cretaceous play level. The main plays are reefs and abrupt margin pinch outs though they are still unproven and conceptual (Fig. 12).

The Mannar Basin is bounded on the landward side by an abrupt-margin. Sedimentary layers onlap and pinch out against this abrupt margin are defined as the abrupt margin pinch out play (Fig. 12). The possible reservoir facies are fans and turbidites. Mudrocks are the anticipated top seal. The basin bounding fault (abrupt margin) provides up dip sealing for the prospects. Similar plays have been proven elsewhere such as in the Jubilee Field in Ghana and Foinaven Field in West of Shetlands. However, these plays involve high seal risk, particularly up-dip (e.g. Biteau et al. 2014). Pearl-1 well and the Pesalai wells have penetrated this section and revealed the presence of high reservoir quality sandstones.

The carbonate platform (most likely shelf margin carbonates) on the basement high is also another unproven/ conceptual play for this play level (Fig. 12). Analogous reservoir facies in carbonate platforms have been documented by various authors (e.g. Read 1982, 1985; Burchette and Wright 1992; Jafarian et al. 2017; Dakhelpour-Ghoveifel et al. 2019). This play is assumed to be spread over a basement high associated with the half-graben, which is located close to the basin margin of the Mannar Basin. Mud rocks are the anticipated seal for the prospects and lateral migration of hydrocarbon from adjacent source intervals is a possibility. However, reservoir quality, sealing and charging are higher risk.

Lower Cretaceous plays have been ready for hydrocarbon accumulation since Campanian times and these plays could be charged by early syn-rift and late syn-rift source rock intervals from ca. 80 Ma to the Recent.

\section{Upper Jurassic or early syn-rift play level}

The Late Jurassic sedimentary strata are named this play level and only one play type has been identified and it is similar to the Upper Cretaceous abrupt margin pinch outs play (Fig. 13). Sediment layers onlap and pinch out towards the basin bounding faults (abrupt margin) in the Mannar Basin (Fig. 13). Possible reservoir facies are slope fans, channel fills, beach and deltas. Although none of the wells in the Mannar Basin have penetrated this section, there is evidence from the adjacent basins. For example, the presence of fluvial sedimentary packages in Sivagana Beds in the Cauvery Basin suggests high reservoir potential (DGH website). The

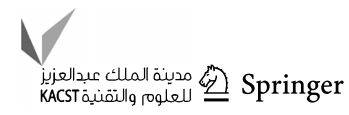




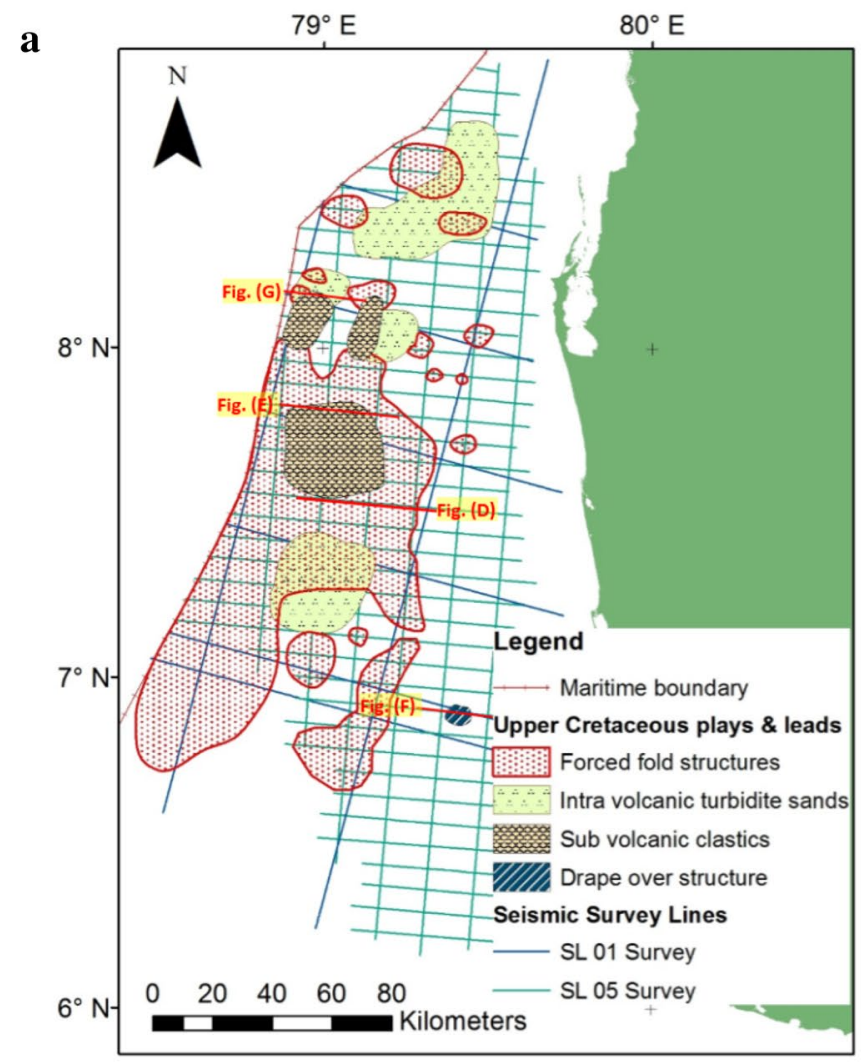

b
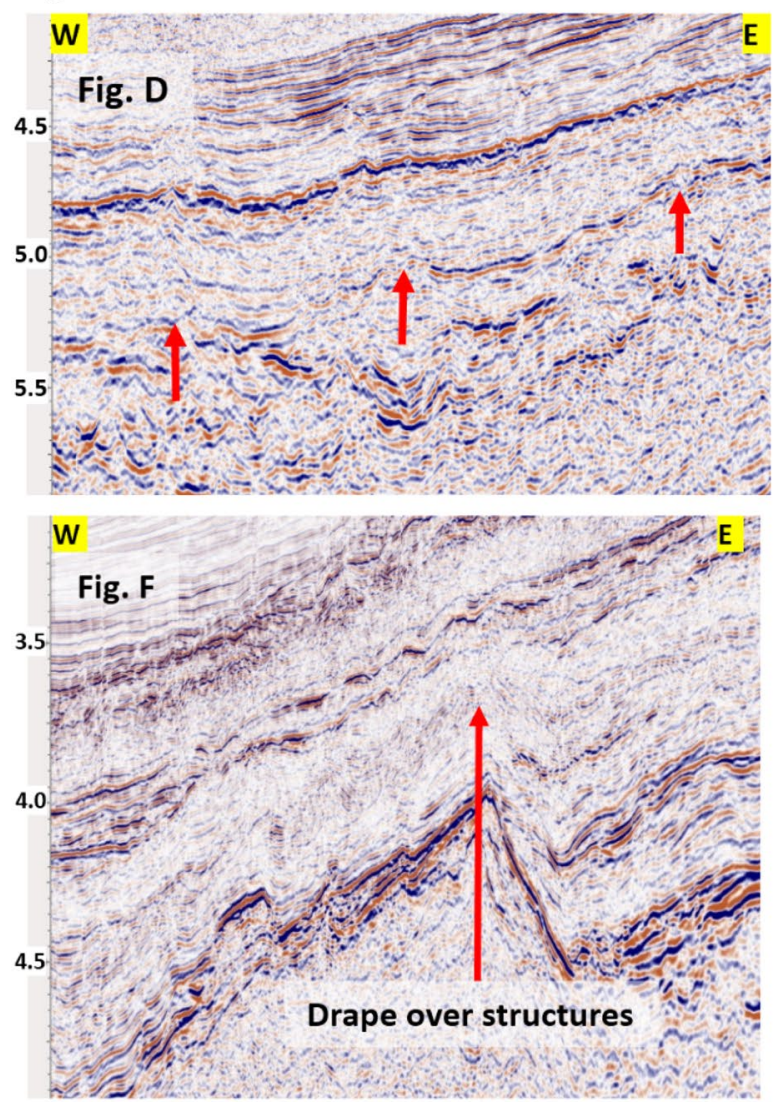
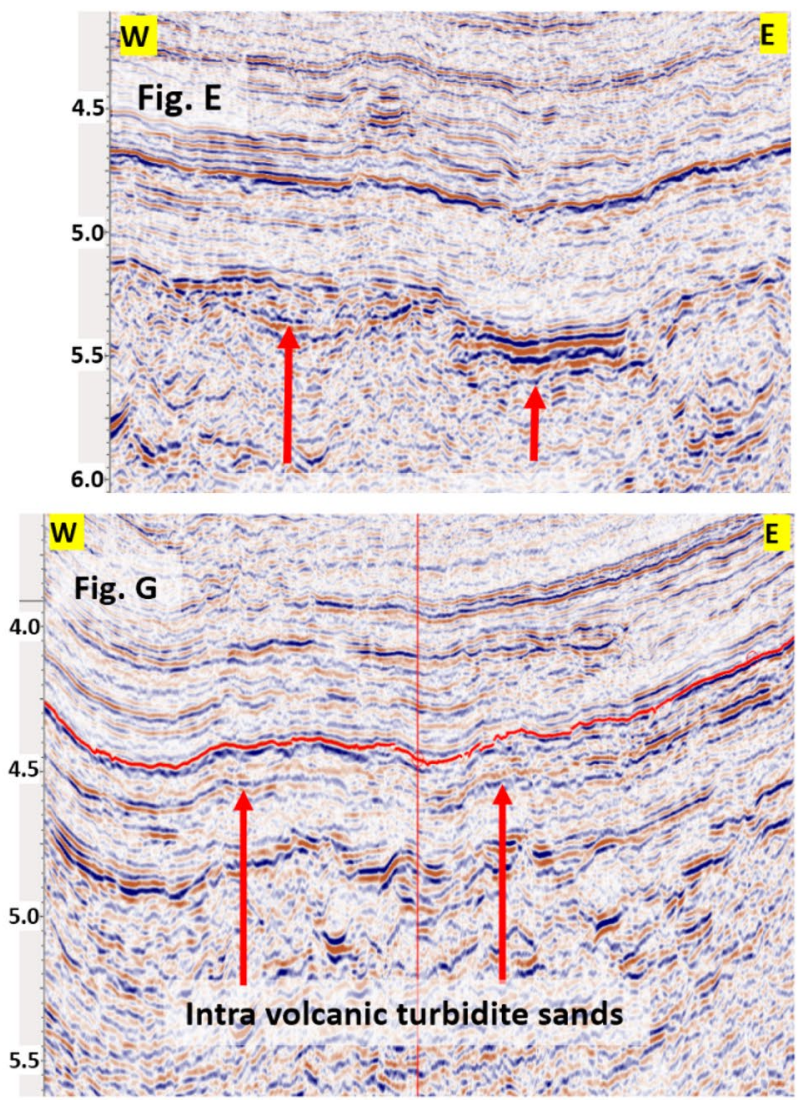
4Fig. 11 a Map showing the distribution of the Upper Cretaceous plays in the Mannar Basin. b Seismic profiles showing potential Upper Cretaceous plays, (D) forced-fold structures, (E) sub-volcanic clastics, $(\mathrm{F})$ drape over structure, $(\mathrm{G})$ intra volcanic turbidite sands

Early syn-rift play has been equipped for hydrocarbon accumulation since the late Albian and these plays could have been charged by early syn-rift source rocks interval from ca. $100 \mathrm{Ma}$ to the Recent.

\section{Basements play level}

The fractured weathered basement is a conceptual play for the Mannar Basin and is located close to the eastern margin of the basin (Fig. 14). The top portion of the basement high (horst associated with half-graben) has been identified as a potential play. This type of play has also been proven for hydrocarbon accumulations in the eastern margin of the Barmer Basin (Bandyopadhyay et al. 2016) and the Bach Ho oilfield in Cuu Long Basin of Vietnam (Cuong and Warren 2009). Weathered basement can provide sufficient porosity and permeability for good quality reservoir characteristics. The existence of a reservoir, reservoir quality and fracturing to provide permeability, and sealing are all high risks. Basement plays have been ready for hydrocarbon accumulation since Campanian times and could be charged by the early syn-rift and late syn-rift source rock intervals from ca. $80 \mathrm{Ma}$ to the Recent.

6. Summary and conclusions

The Mannar Basin is a frontier sedimentary basin. Recent hydrocarbon exploration acquired $2 \mathrm{D}$ and $3 \mathrm{D}$ seismic data and also drilled four exploration wells. The Dorado and Barracuda gas/condensate discoveries in 2011 confirmed the active petroleum system. The tectonostratigraphy reveals that the Mannar Basin is the oldest sedimentary basin in Sri Lanka evolving since Late Jurassic times and contains greater sediment thickness than the Cauvery and Lanka Basins. The basin experienced two rifting events followed by a post-rift phase with a thermal sag period and inversion period. Three potential source rocks levels have been interpreted at Maastrichtian-Campanian, Albian-Aptian and Late Jurassic stratigraphic levels. The basin modelling suggests that mature potential source rocks exist below the Maastrichtian-Campanian. The highest potential source rocks are predicted to be Albian-Aptian. Late Jurassic source rocks have more potential for gas while other sources have potential for both oil and gas. Five play levels were identified in the Mannar Basin: Tertiary, Upper Cretaceous, Lower Cretaceous, Upper Jurassic or early syn-rift and the basement play. Tertiary plays are dominated by submarine fans charged by all the interpreted source rock intervals from end of Paleocene times onward and have a higher potential for oil. The main Upper Cretaceous plays are sands interfingering flood basalts and forced folds. The Upper Cretaceous plays could also be charged by all the interpreted source rock intervals from end of Maastrichtian times onward, and have a potential for both oil and gas. They have higher oil potential close to the basin margin and higher gas potential towards the basin centre. The Lower Cretaceous plays are pinchouts and reefs charged by early syn-rift and late syn-rift source rock intervals from Campanian times onwards. The Lower Cretaceous plays have a higher potential for oil. The Upper Jurassic or early syn-rift plays consist of sandstone pinchouts charged by early syn-rift source rocks since Albian times. The half-grabens show a higher potential for gas. Weathered basement plays could be charged by the source rock intervals of early syn-rift and late syn-rift since Campanian times. Seals for these plays are interfingering mudrocks and marginal faults but the flood basalt layer in the basin may also have acted as a barrier for hydrocarbon migration. This volcanic layer also inhibits the penetration of seismic energies to pre-Tertiary sedimentary layers and resulting in a drop in quality of seismic data. Therefore, interpretations of plays and leads have become a major challenge for pre-Tertiary sedimentary layers. The Mannar Basin has a low risk for the source and reservoir, and seal and traps yet to be resolved. 

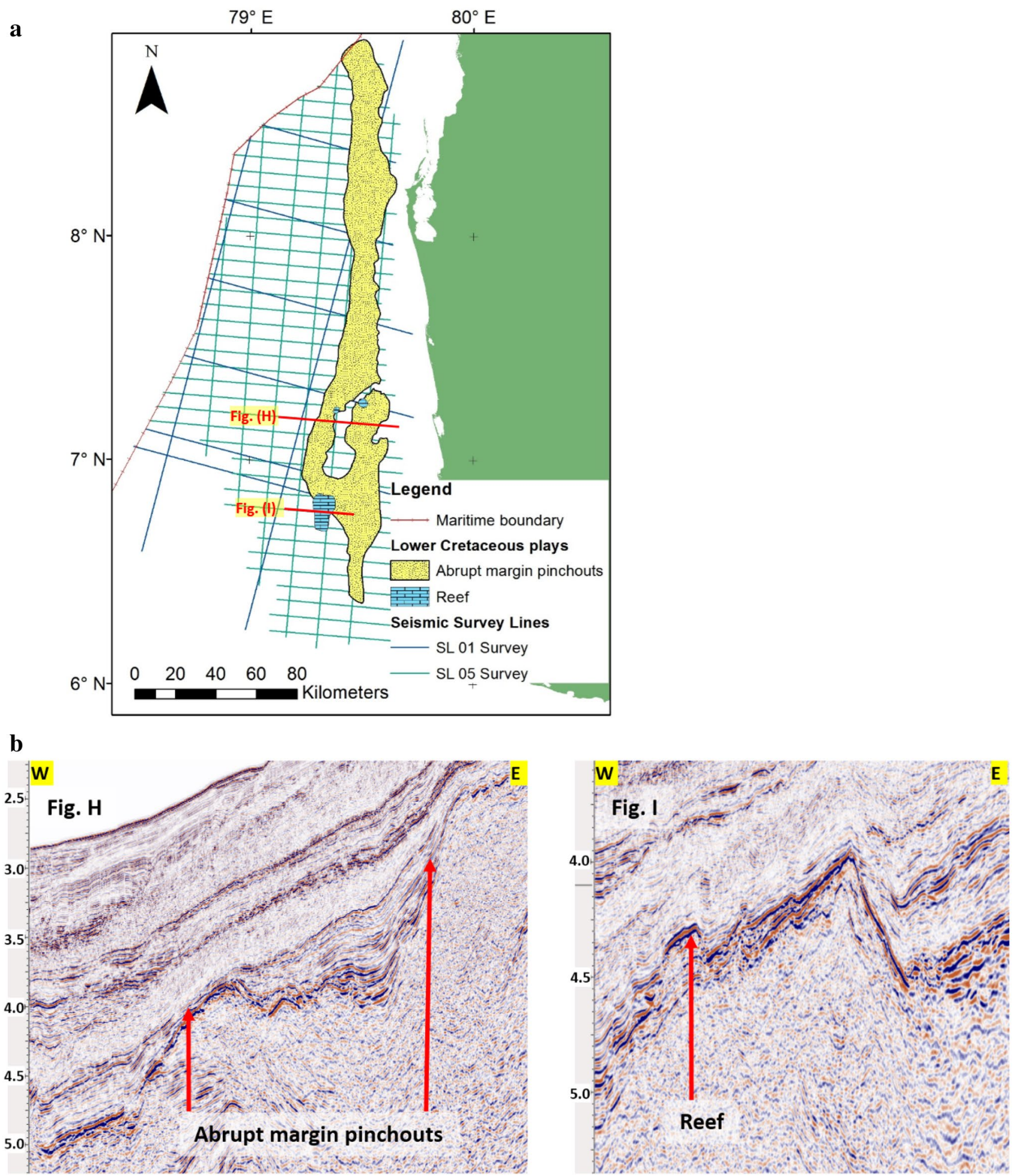

Fig. 12 a Map showing the distribution of the Lower Cretaceous plays in the Mannar Basin. b Seismic profiles showing potential plays in the Lower Cretaceous play level, (H) abrupt margin pinchouts, (I) Reef 


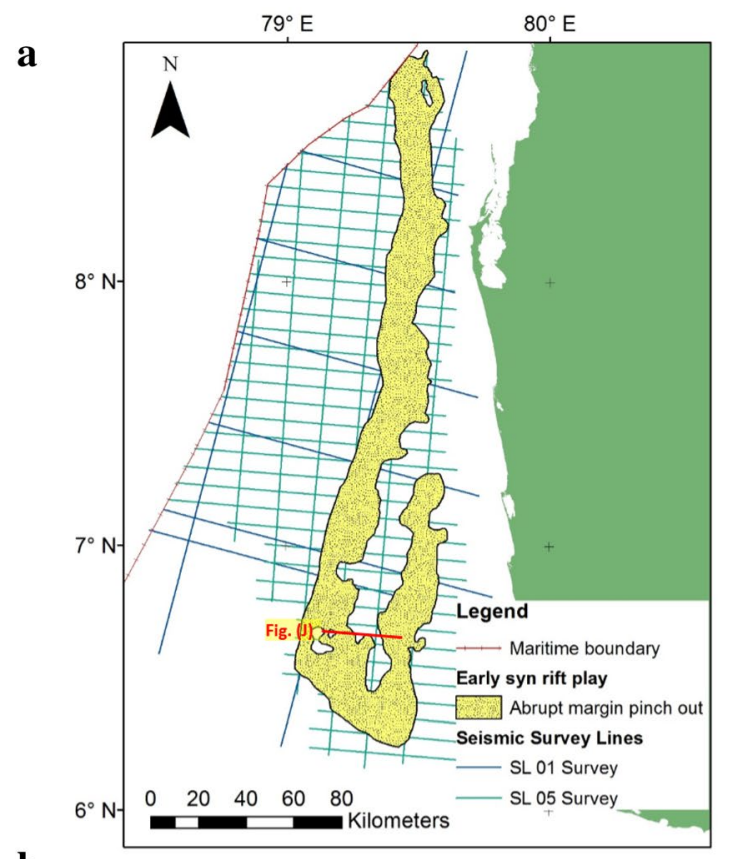

b

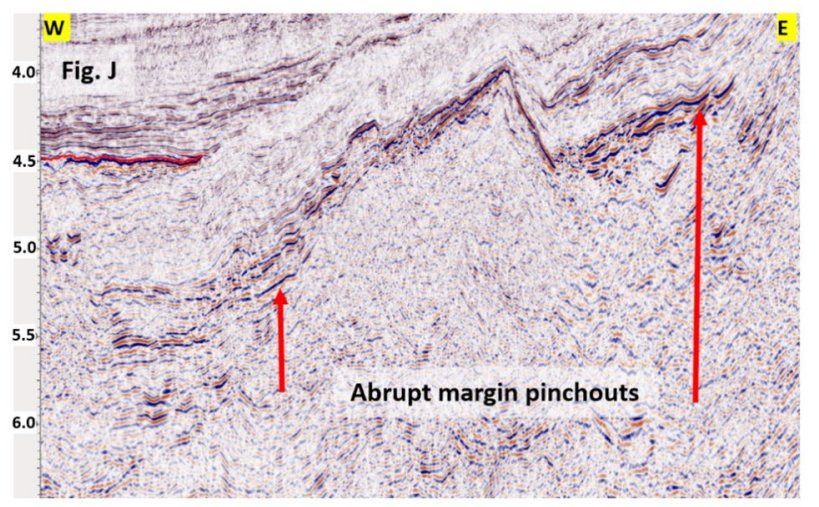

Fig. 13 a Map showing the distribution of the early syn-rift plays in the Mannar Basin. b Seismic profile showing the early syn-rift play, (J) abrupt margin pinchouts

Acknowledgements We gratefully acknowledge the Petroleum Resources Development Secretariat (PRDS), Sri Lanka for granting permission to access the data and facilities for the research work. We thank Turgay Ertekin (Editor-in-Chief) and two anonymous reviewers for their comments and suggestions on a previous version of the manuscript. We specially thank Adrian Heafford, Senior Geologist, IHS Markit, UK for improving the manuscript.

Open Access This article is licensed under a Creative Commons Attribution 4.0 International License, which permits use, sharing, adaptation, distribution and reproduction in any medium or format, as long as you give appropriate credit to the original author(s) and the source, provide a link to the Creative Commons licence, and indicate if changes were made. The images or other third party material in this article are included in the article's Creative Commons licence, unless indicated otherwise in a credit line to the material. If material is not included in the article's Creative Commons licence and your intended use is not permitted by statutory regulation or exceeds the permitted use, you will

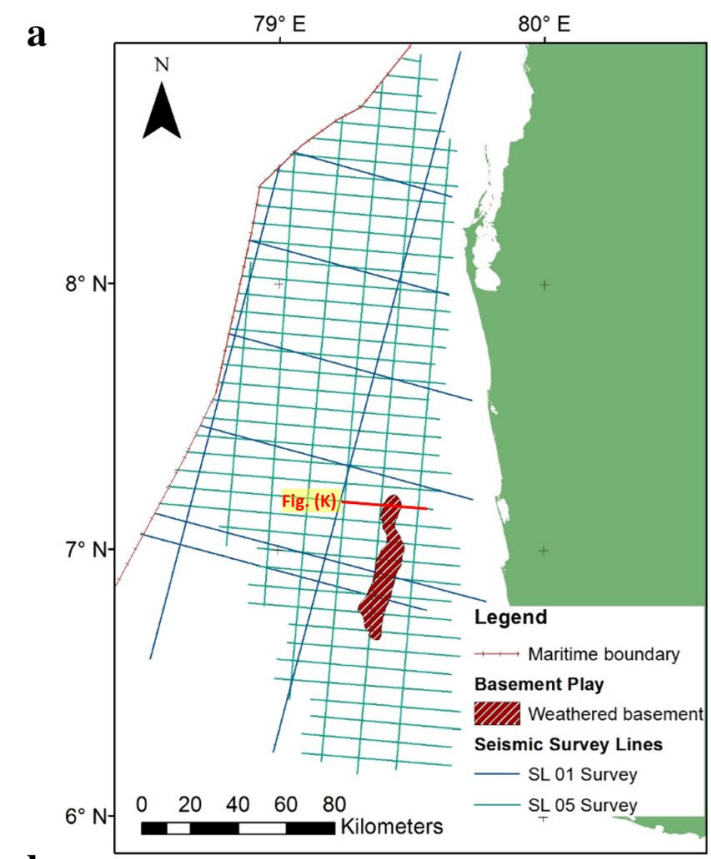

b

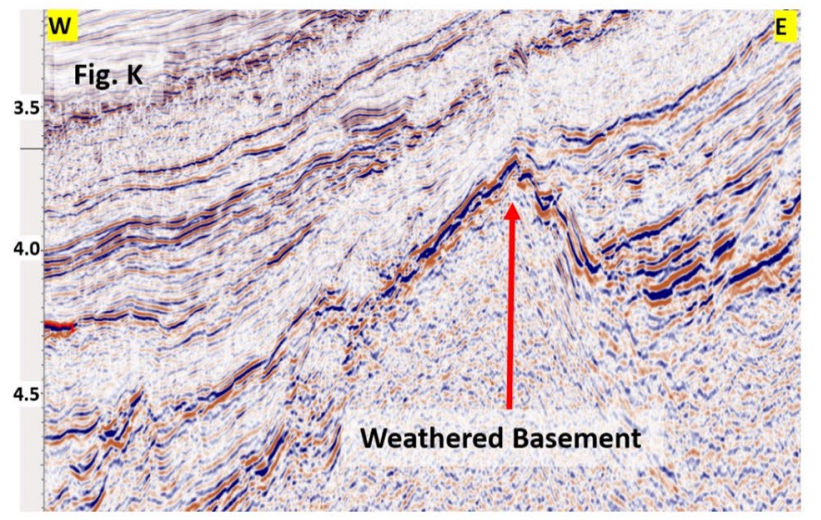

Fig. 14 a Map showing the distribution of the basement plays in the Mannar Basin. b Seismic profile showing the basement play, (K) weathered basement

need to obtain permission directly from the copyright holder. To view a copy of this licence, visit http://creativecommons.org/licenses/by/4.0/.

\section{References}

Allen PA, Allen JR (2005) Basin analysis, principles and applications, 2nd edn. Wiley-Blackwell Science Ltd, Hoboken, pp 309-396

Arthur MA, Schlanger SO (1979) Cretaceous "oceanic anoxic events" as causal factors in development of reef-reservoired giant oil fields. AAPG Bull 63:870-885

Bandara AS, Weerasinghe DA, Ratnayake AS (2020) Determination of the regional and residual gravity anomalies to reconstruct basin structures of the Cauvery Basin. J Geol Soc Sri Lanka 21:21-31

Bandyopadhyay A, Sabyasachi D, Yadav RK, Singh N, Mohapatra $P$ (2016) Naturally fractured and weathered basement play in 
Barmer Basin. In: PETROTECH, the 12th international oil \& gas conference \& exhibition, New Delhi

Biteau JJ, Blaizot M, Janodet D, de Clarens P (2014) Recent emerging paradigms in hydrocarbon exploration. First Break 32:49-58

Burchette TP, Wright VP (1992) Carbonate ramp depositional systems. Sediment Geol 79:3-57

Cernock PJ (1976) Hydrocarbon source rock evaluation study organic geochemical analyses of conventional core samples. Geochemical Laboratories, Ceylon Petroleum Corporation, Colombo, pp 7-9

Cooray PG (1984) An introduction to the geology of Sri Lanka, 2nd edn. Ceylon National Museum Publication, Colombo, pp 81-169

Cuong TX, Warren JK (2009) Bach Ho filed, a fractured granitic basement reservoir, Cuu Long Basin, Offshore SE Vietnam: a "buriedhill" play. J Pet Geol 32:129-156

Dakhelpour-Ghoveifel J, Shegeftfard M, Dejam M (2019) Capillarybased method for rock typing in transition zone of carbonate reservoirs. J Pet Explor Prod Technol 9:2009-2018

Desa M, Ramana MV, Ramprasad T (2006) Seafloor spreading magnetic anomalies south off Sri Lanka. Mar Geol 229:227-240

Doust H (2010) The exploration play: what do we mean by it? AAPG Bull 94:1657-1672

Du Toit AL (1920) The Karoo dolerites of South Africa: a study of hypabyssal injection. Trans Geol Soc S Afr 23:1-42

Galushkin Y (2016) The lithosphere extension and hydrocarbon generation in the eastern continental passive margin of India. In: Galushkin Y (ed) Non-standard problems in basin modelling. Springer, Cham, pp 31-63

Hansen DM, Cartwright JA (2006) The three-dimensional geometry and growth of forced folds above saucer-shaped igneous sills. J Struct Geol 28:1520-1535

Hotz PE (1952) Form of diabase sheets in south eastern Pennsylvania. Am J Sci 250:375-388

Ichron limited (2012a) A biostratigraphical evaluation and petrographical, diagenetic and reservoir quality assessment of well Dorado91H/1Z. Cairn Lanka Pty Limited, Mannar Basin

Ichron limited (2012b) A biostratigraphical evaluation and petrographical, diagenetic and reservoir quality assessment of well Barracuda-1G/1. Cairn Lanka Pty Limited, Mannar Basin

Ichron limited (2012c) A biostratigraphical evaluation and petrographical, diagenetic and reservoir quality assessment of well Dorado North 82K/1. Cairn Lanka Pty Limited, Mannar Basin

Ichron limited (2013) A biostratigraphical evaluation and petrographical, diagenetic and reservoir quality assessment of well Wallago 50H/1. Cairn Lanka Pty Limited, Mannar Basin

Jafarian A, Fallah-Bagtash R, Mattern F, Heubeck C (2017) Reservoir quality along a homoclinal carbonate ramp deposit: the Permian Upper Dalan Formation, South Pars Field, Persian Gulf Basin. Mar Pet Geol 88:587-604

Kularathna EKCW, Pitawala HMTGA, Senarathne A, Senevirathne BSMCK, Weerasinghe DA (2015) Forced-fold structures in the Mannar Basin, Sri Lanka: modes of occurrence, development mechanism and contribution for the petroleum system. J Geol Soc Sri Lanka 17:53-63

Magoon LB, Dow WG (1994) The petroleum system from source to trap. AAPG Bull 75:3

Mizukoshi I, Sunouchi H, Saki T, Sato S, Tanahashi M (1986) Preliminary report of geological geophysical surveys off Amery Ice Shelf, East Antarctica. Mem Nat Inst Polar Res Spec Issue Jpn 43:48-61

Mortensen PB, Hovland M, Brattegard T, Farestveit R (1995) Deep water bioherms of the scleractinian coral Lophelia pertusa (L.) at $64 \mathrm{~N}$ on the Norwegian Shelf: structure and associated emgafauna. Sarsia 80:145-158
Mukherjee J, Mahapatra MP (2013) Evaluate uncertainty form Basin to Prospect scale to improve exploration success. In: 10th Biennial international conference \& exposition. Kochi

Mullins HT, Newton CR, Heath K, Van Buren HM (1981) Modern deep-water coral mounds north of Little Bahama bank: criteria for recognition of deep-water coral bioherms in the rock record. J Sediment Res 51:999-1013

Nagendra R, Reddy AN (2017) Major geologic events of the Cauvery Basin, India and their correlation with global signatures-a review. J Palaeogeog 6:69-83

Nyantakyi EK, Li T, Hu WS, Borkloe JK (2013) Structures and hydrocarbon prospects in emi field, offshore Niger Delta. Int J Res Eng Technol 02:84-91

Olayiwola SO, Dejam M (2019) A comprehensive review on interaction of nanoparticles with low salinity water and surfactant for enhanced oil recovery in sandstone and carbonate reservoirs. Fuel 241:1045-1057

Pepper AS, Corvi PJ (1995) Simple kinetic models of petroleum formation. Part I: oil and gas generation from kerogen. Mar Pet Geol 12:291-319

Ramana MV, Ramprasad T, Desa M (2001) Seafloor spreading magnetic anomalies in the Enderby Basin, East Antarctica. Earth Planet Sci Lett 191:241-255

Ratnayake AS (2016) Region wide geodynamic analyses of the Cenozoic carbonate burial in Sri Lanka related to climate and atmospheric $\mathrm{CO}_{2}$. Int J Econ Environ Geol 7:1-9

Ratnayake AS, Sampei Y (2015a) Characterization of organic matter and depositional environment of the Jurassic small sedimentary basins exposed in the northwest onshore area of Sri Lanka. Res Org Geochem 31:15-28

Ratnayake AS, Sampei Y (2015b) Preliminary prediction of the geothermal activities in the frontier Mannar Basin, Sri Lanka. J Geol Soc Sri Lanka 17:19-29

Ratnayake AS, Sampei Y (2019) Organic geochemical evaluation of contamination tracers in deepwater well rock cuttings from the Mannar Basin, Sri Lanka. J Pet Explor Prod Technol 9:989-996

Ratnayake AS, Sampei Y, Kularathne CW (2014) Stratigraphic responses to major depositional events from the Late Cretaceous to Miocene in the Mannar Basin, Sri Lanka. J Geol Soc Sri Lanka 16:5-18

Ratnayake AS, Sampei Y, Kularathne CW (2017) Current status of hydrocarbon exploration in Sri Lanka. Int J Oil Gas Coal Technol 16:377-389

Ratnayake AS, Kularathne CW, Sampei Y (2018) Assessment of hydrocarbon generation potential and thermal maturity of the offshore Mannar Basin, Sri Lanka. J Pet Explor Prod Technol 8:641-654

Read JF (1982) Carbonate platforms of passive (extensional) continental margins: types, characteristics and evolution. Tectonophysics $81: 195-212$

Read JF (1985) Carbonate platform facies models. AAPG Bull 69:1-21

Richards M, Bowman M (1998) Submarine fans and related depositional systems II: variability in reservoir architecture and wireline log character. Mar Pet Geol 15:821-839

Royer JY, Coffin MF (1992) Jurassic to Eocene plate reconstructions in the Kerguelen Plateau Region. Proc Ocean Drill Prog Sci Results 120:917-928

Rullkötter J, Mukhopadhyaya PK (1984) Jurassic and mid-Cretaceous carbonaceous claystones in the Western (DSDP Leg 76) and eastern (DSDP Leg 79) North Atlantic. Org Geochem 6:761-767

Schlanger SO, Jenkyns HC (1976) Cretaceous anoxic events: causes and consequences. Neth J Geosci 55:179-184

Schlich R (1982) The Indian Ocean: aseismic ridges, spreading centers, and oceanic basins. The Ocean Basins and Margins, Plenum Press, New York, pp 51-147 
Shaw RD (2002) TGS-NOPEC SL01-phase one offshore Sri Lanka seismic survey interpretation report. New South Global Pty Ltd, Colombo, pp 1-45

Stanca R, Kearns H, Paton D, Hodgson N, Rodriguez K, Hussein AA (2016) Offshore Somalia: crustal structure and implications on thermal maturity. First Break 34:61-67

Tissot B, Welte DH (1984) Petroleum formation and occurrence. Springer, Berlin, pp 655-656
Turgeon SC, Creaser RA (2008) Cretaceous oceanic anoxic event 2 triggered by a massive magmatic episode. Nature 454:323-326

Wilson JB (1979) 'Patch' development of the deep-water coral Lophelia pertusa (L.) on Rockall Bank. J Mar Biol Assoc UK 59:165-177

Publisher's Note Springer Nature remains neutral with regard to jurisdictional claims in published maps and institutional affiliations. 